\title{
Estimating the storage of anthropogenic carbon in the subtropical Indian Ocean: a comparison of five different approaches
}

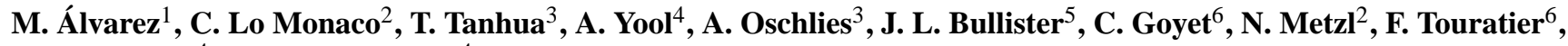 \\ E. McDonagh ${ }^{4}$, and H. L. Bryden ${ }^{4}$ \\ ${ }^{1}$ IMEDEA (CSIC-UIB), Miquel Marqués 21, 07190 Esporles, Spain \\ ${ }^{2}$ LOCEAN/IPSL, Université Paris 6 - place Jussieu 4, 75252 Paris, France \\ ${ }^{3}$ IFM-GEOMAR, Düsternbrooker Weg 20, 24105 Kiel, Germany \\ ${ }^{4}$ NOCS, Waterfront Campus European Way, Southampton, SO14 3ZH, UK \\ ${ }^{5}$ NOAA/Pacific Marine Environmental Laboratory, Seattle, Washington, USA \\ ${ }^{6}$ IMAGES, Université de Perpignan, 52 avenue Paul Alduy, 66860 Perpignan, France
}

Received: 5 November 2008 - Published in Biogeosciences Discuss.: 13 January 2009

Revised: 20 April 2009 - Accepted: 20 April 2009 - Published: 27 April 2009

\begin{abstract}
The subtropical Indian Ocean along $32^{\circ} \mathrm{S}$ was for the first time simultaneously sampled in 2002 for inorganic carbon and transient tracers. The vertical distribution and inventory of anthropogenic carbon $\left(\mathrm{C}_{\mathrm{ANT}}\right)$ from five different methods: four data-base methods $\left(\Delta C^{*}\right.$, TrOCA, TTD and IPSL) and a simulation from the OCCAM model are compared and discussed along with the observed CFC-12 and $\mathrm{CCl}_{4}$ distributions. In the surface layer, where carbonbased methods are uncertain, TTD and OCCAM yield the same result $\left(7 \pm 0.2 \mathrm{molC} \mathrm{m}^{-2}\right)$, helping to specify the surface $\mathrm{C}_{\mathrm{ANT}}$ inventory. Below the mixed-layer, the comparison suggests that $\mathrm{C}_{\mathrm{ANT}}$ penetrates deeper and more uniformly into the Antarctic Intermediate Water layer limit than estimated from the much utilized $\Delta C^{*}$ method. Significant $\mathrm{CFC}-12$ and $\mathrm{CCl}_{4}$ values are detected in bottom waters, associated with Antarctic Bottom Water. In this layer, except for $\Delta \mathrm{C}^{*}$ and OCCAM, the other methods detect significant $\mathrm{C}_{\mathrm{ANT}}$ values. Consequently, the lowest inventory is calculated using the $\Delta \mathrm{C}^{*}$ method $\left(24 \pm 2 \mathrm{molC} \mathrm{m}^{-2}\right)$ or OCCAM $\left(24.4 \pm 2.8 \mathrm{molC} \mathrm{m}^{-2}\right)$ while TrOCA, TTD, and IPSL lead to higher inventories $(28.1 \pm 2.2,28.9 \pm 2.3$ and $30.8 \pm 2.5 \mathrm{molC} \mathrm{m}^{-2}$ respectively). Overall and despite the uncertainties each method is evaluated using its relationship with tracers and the knowledge about water masses in the subtropical Indian Ocean. Along $32^{\circ} \mathrm{S}$ our best estimate for the mean $\mathrm{C}_{\mathrm{ANT}}$ specific inventory is $28 \pm 2 \mathrm{molC} \mathrm{m}^{-2}$. Comparison exercises for data-based $\mathrm{C}_{\mathrm{ANT}}$ methods along with
\end{abstract}

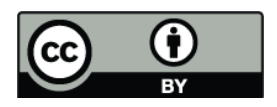

Correspondence to: M. Álvarez (marta.alvarez@uib.es) time-series or repeat sections analysis should help to identify strengths and caveats in the $\mathrm{C}_{\mathrm{ANT}}$ methods and to better constrain model simulations.

\section{Introduction}

The fate of the anthropogenic $\mathrm{CO}_{2}\left(\mathrm{C}_{\mathrm{ANT}}\right)$ emissions to the atmosphere is one of the critical concerns in our attempts to better understand and possibly predict global change and its impact on society (IPCC, 2007). Quantifying the global carbon cycle is still the subject of much scientific effort, especially where new processes and carbon pathways have to be considered (Cole et al., 2007; Duarte et al., 2005; Prairie and Duarte, 2007). While being a well-known and significant process, the uptake of $\mathrm{C}_{\mathrm{ANT}}$ by the world ocean is not well-constrained at present and its magnitude and variability may change in the future. Different approaches to estimate the global oceanic $\mathrm{C}_{\mathrm{ANT}}$ uptake have arrived at essentially the same number, about $2 \mathrm{PgC} \mathrm{yr}^{-1}$ (Wetzel et al., 2005). However, despite this general agreement, questions about the reliability of these estimates remain.

The Joint SOLAS-IMBER implementation plan has identified the research priorities for ocean carbon research, among them the separation of natural from anthropogenic carbon, the oceanic storage and transport of $\mathrm{C}_{\mathrm{ANT}}$ and the effect of decreasing $\mathrm{pH}$, ocean acidification, on the marine biogeochemical cycles, ecosystems and their interactions (www. imber.info/products/Carbon_Plan_final.pdf). Large impacts of ocean acidification are expected to occur in high latitudes, i.e. the Southern (Bopp et al., 2001; Orr et al., 2005) and the

Published by Copernicus Publications on behalf of the European Geosciences Union. 
Arctic (Bellerby et al., 2005) Oceans, where large regional discrepancies between estimated $\mathrm{C}_{\mathrm{ANT}}$ inventory are found (Vázquez-Rodríguez et al., 2009).

The first attempts to estimate $\mathrm{C}_{\mathrm{ANT}}$ from oceanic measurements were based on the back-calculation method proposed independently by Brewer (1978) and Chen and Millero (1979). This method was reformulated by Gruber et al. (1996) and specific improvements were proposed for the Atlantic Ocean (Pérez et al., 2002) and Southern Ocean (Lo Monaco et al., 2005a). Several other methods based upon completely different concepts also arose; such as one based on water mass mixing (the MIX method; Goyet et al., 1999), another based on estimating Transit Time Distribution (TTD) or ages from transient tracers as $\mathrm{CFCs}, \mathrm{SF}_{6}$ or $\mathrm{CCl}_{4}$ (TTD method; Hall et al., 2002), and one based on a composite tracer (TrOCA method; Touratier et al. 2004a, b; Touratier et al., 2007). In addition there are simulations from threedimensional Ocean General Circulation Models (OGCM) (Orr et al., 2001). Despite these efforts, no clear conclusion has been achieved about the best method after several comparison exercises (Coatanoan et al., 2001; Feely, 2001; Hall et al., 2004; LoMonaco et al., 2005b; Sabine and Feely, 2001; Wanninkhof et al., 1999; Waugh et al, 2006; Touratier et al., 2007), which are still necessary and on-going, for example, within the Integrated Project CARBOOCEAN for the Atlantic basin (Vázquez-Rodríguez et al., 2009).

The contribution of the Indian Ocean to the global $\mathrm{C}_{\mathrm{ANT}}$ storage was initially discussed in Chen (1993) and Sabine et al. (1999) and later in Sabine et al. (2004) from a global perspective. While the ocean volume of the Indian Ocean is $20 \%$ less than that of the Atlantic, the total $\mathrm{C}_{\mathrm{ANT}}$ inventory of the Indian Ocean is only half that of the Atlantic, and it contributes $\sim 21 \%$ to the global ocean $\mathrm{C}_{\mathrm{ANT}}$ inventory (Sabine et al., 2004). The relevant areas or processes introducing $C_{\mathrm{ANT}}$ into the Indian Ocean are:

1. full equilibration of the upper mixed layer;

2. the formation of Red Sea - Persian Gulf Intermediate water (Papaud and Poisson, 1986; Mecking and Warner, 1999) in the northwestern Indian Ocean spreading equatorward;

3. the formation of Subantarctic Mode Water (SAMW) north of the Subantarctic Front (McCartney, 1977), including the large volume of SAMW being formed in the southeast Indian Ocean (e.g., Sloyan and Rintoul, 2001; Sallée et al., 2006) and transported equatorwards; and,

4. the formation of Antarctic Intermediate Water (AAIW), usually delineating the lower limit of $\mathrm{C}_{\mathrm{ANT}}$ penetration (Sabine et al., 2004) in the Indian Ocean.

The thermostad associated with SAMW is formed by deep mixing in winter on the equatorward side of the Subantarctic Front (McCartney, 1977), and is found at about $400-600 \mathrm{~m}$.
SAMW is linked to AAIW in the Southeast Pacific (McCartney, 1977) circulating in this basin through subduction. AAIW of the South Atlantic and Indian oceans is produced in the confluence of the Malvinas and Brazil currents by injection of surface water into the subtropical gyre, which then circulates eastwards and northwards in the South Atlantic and Indian Oceans, where no other AAIW sources are found (Talley, 1996; Hanawa and Talley, 2001).

Deep water formation is another important mechanism sequestering $\mathrm{C}_{\mathrm{ANT}}$ into the ocean. The formation and transport of North Atlantic Deep Water (NADW) is associated with high $\mathrm{C}_{\mathrm{ANT}}$ inventories present in the North Atlantic (e.g., Álvarez et al., 2003; Sabine et al., 2004; Touratier and Goyet 2004b). Another major pathway theoretically introducing $\mathrm{C}_{\mathrm{ANT}}$ into the deep ocean could be the production of Antarctic Bottom Water (AABW). However; large discrepancies exist in estimates of the role of the Southern Ocean in the $\mathrm{C}_{\mathrm{ANT}}$ uptake and storage. Both OGCMs (Caldeira and Duffy, 2000; Orr et al., 2001) and inversion estimates based on OGCMs but constrained with data (Mikaloff Fletcher et al., 2006) find a high $C_{\text {ANT }}$ uptake but low $C_{\text {ANT }}$ storage in the Southern Ocean, with high uncertainties. These studies also find high $\mathrm{C}_{\mathrm{ANT}}$ transport northwards toward the Antarctic convergence zone. The low storage is supported by databased estimates (e.g., Poisson and Chen, 1987; Gruber, 1998; Hoppema et al., 2001) that rely on factors such as the very high Revelle factor of these waters, the relatively short contact time with the surface between upwelling and subduction and decreased $\mathrm{CO}_{2}$ uptake due to the presence of seaice. However, these findings are contradicted by the detection and accumulation of CFCs in Antarctic deep and bottom waters (e.g., Meredith et al., 2001; Orsi et al., 2002) and the $\mathrm{C}_{\mathrm{ANT}}$ accumulation detected south of Australia (McNeil et al., 2001) and in the South Atlantic Ocean (Murata et al., 2008), or using the TTD technique for the whole Southern Ocean (Waugh et al., 2006). Recent carbon-based studies also detect significant $\mathrm{C}_{\mathrm{ANT}}$ accumulation in deep and bottom waters of the Southern Ocean (Lo Monaco et al., 2005a, b; Sandrini et al., 2007).

This study is a comparison exercise between different data-based (carbon-based and TTD) techniques for estimating $\mathrm{C}_{\mathrm{ANT}}$ applied along a transoceanic section along $32^{\circ} \mathrm{S}$ in the Indian Ocean. Differences among the $\mathrm{C}_{\mathrm{ANT}}$ distributions and inventories are presented, and the strengths and weaknesses of the individual methods are discussed. To provide an independent and unrelated comparison, results from an OGCM are presented alongside the data-based techniques. The final aim is to obtain the best $\mathrm{C}_{\mathrm{ANT}}$ inventory in the subtropical Indian Ocean with new data and based on different approaches. 


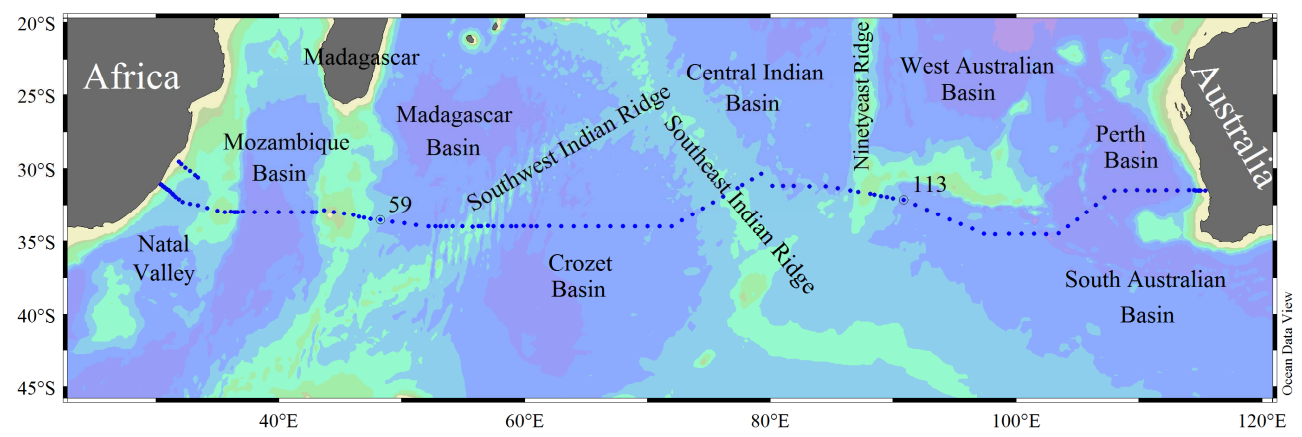

Fig. 1. Positions of the CTD stations occupied during the CD139 cruise crossing the Indian Ocean. Stations 59 and 113 are marked.

\section{Data set}

During March-April 2002, cruise 139 of RRS Charles Darwin (CD139), a trans-Indian hydrosection was made nominally along $32^{\circ} \mathrm{S}$ (Bryden et al., 2003). The section used here consisted of 133 full-depth stations (Fig. 1) with a typical spacing over the deep basins of $90 \mathrm{~km}$ and a maximum of $120 \mathrm{~km}$. Over the shelf and other topography the station spacing was decreased.

CTD data were taken with a SeaBird 9/11 plus system. Discrete samples for dissolved oxygen $\left(\mathrm{O}_{2}\right)$ were analysed by a semi-automated whole-bottle Winkler titration unit with spectrophotometric end-point detection. Inorganic nutrient concentrations were measured using a Skalar San Plus autoanalyser, configured according to the manufacturer's specifications (Kirkwood, 1995). The overall accuracy for $\mathrm{O}_{2}$, nitrate, phosphate and silicate is 1, 0.1, 0.01 and $0.6 \mu \mathrm{mol} \mathrm{kg}^{-1}$, respectively.

Chlorofluorocarbon (CFC) samples were collected from the same Niskin bottles sampled for Total Alkalinity and pH. Concentrations of CFC-11 and CFC-12 in seawater were measured in about 2100 water samples using shipboard electron capture gas chromatography (EC-GC) techniques similar to those described by Bullister and Weiss (1988). A subset $(\sim 540)$ of the water bottles sampled for CFCs were also sampled and analyzed for dissolved carbon tetrachloride $\left(\mathrm{CCl}_{4}\right)$ on a separate analytical system using similar techniques. CFC and $\mathrm{CCl}_{4}$ concentrations are reported in picomoles per kilogram seawater $\left(\mathrm{pmol} \mathrm{kg}^{-1}\right)$. The overall accuracy for dissolved CFC-11 and CFC-12 measurements was estimated to be $2 \%$ or $0.010 \mathrm{pmol} \mathrm{kg}^{-1}$ (whichever is greater) and $3 \%$ or $0.012 \mathrm{pmol} \mathrm{kg}^{-1}$ for $\mathrm{CCl}_{4}$ measurements.

The CFC-12 age ( $\tau$ ) of any water sample has been calculated following Doney and Bullister (1992) assuming 100\% initial saturation. Reconstructed CFC-12 annual mean dry air mole fractions in the Southern Hemisphere were taken after Walker et al. (2000), extended with yearly mean values from the AGAGE sampling network. Note that the TTD method uses a different approach to estimate ages from CFCs.
The CD139 trans-Indian section was completely analysed for $\mathrm{pH} ; 69$ stations were analysed for Total Alkalinity (TA), typically every other station. Since these two variables allow the carbonate chemistry system to be fully constrained, Total Inorganic Carbon $\left(\mathrm{C}_{T}\right)$ was not routinely measured. However, $C_{T}$ samples were collected at 4 stations and were analysed post-cruise on land as quality control.

$\mathrm{pH}$ was measured spectrophotometrically following Clayton and Byrne (1993) using a seawater m-cresol purple dye solution. Replicate analysis from deep Niskin bottles shows a reproducibility of \pm 0.0009 . $\mathrm{pH}$ analysis on CRM samples were also performed. For more details about the $\mathrm{pH}$ analyses and quality control see Appendix A1.

TA was measured using a double end-point automatic potentiometric titration (Pérez and Fraga, 1987). Concentrations are given in $\mu \mathrm{mol} \mathrm{kg-sw}{ }^{-1}$. Determinations of TA on $\mathrm{CRM}$ were made during the cruise to monitor the titrator performance. At a test station, the whole set of bottles were closed at the same depth. The resulting TA standard deviation of a total of 24 analyses over 12 bottle samples was $1.04 \mu \mathrm{mol} \mathrm{kg}^{-1}$. For more details about the TA analyses and quality control see Appendix A2.

$\mathrm{C}_{T}$ samples were collected in $500 \mathrm{~mL}$ borosilicate bottles, immediately poisoned with $\mathrm{HgCl}_{2}$ and stored in the dark until analyzed on shore. $\mathrm{C}_{T}$ was measured in the lab using a coulometer with a SOMMA (Single Operator Multiparameter Metabolic Analyzer) inlet system (Johnson et al., 1993). CRM were used to correct any offset in the analysis.

$\mathrm{C}_{T}$ was also calculated from the sample $\mathrm{pH}_{T 25}$ (error 0.0009) and TA (error $1 \mu \mathrm{mol} \mathrm{kg}^{-1}$ ) using Lueker et al. (2000) constants, consequently the calculated $\mathrm{C}_{T}$ error is about $4 \mu \mathrm{mol} \mathrm{kg}^{-1}$. Salinity-normalized calculated $\mathrm{C}_{T}$ values compared to normalized coulometric $\mathrm{C}_{T}\left(\mathrm{NC}_{T}\right.$ coul $)$ measurements with a linear relationship: $\mathrm{NC}_{T}$ calc $=1.006 \pm 0.007 \times \mathrm{NC}_{T}$ coul $-14 \pm 15 \quad\left(r^{2}=0.998\right.$, $\mathrm{n}=51,0 \pm 4 \mu \mathrm{mol} \mathrm{kg}{ }^{-1}$, mean $\pm \mathrm{STD}$ of the residuals). See Appendix A3 for further information.

The above results indicate the high quality and internal consistency of the $\mathrm{CD} 139 \mathrm{CO}_{2}$ data base. Despite this, we have also performed a crossover analysis using 
WOCE-GLODAP cruises overlapping our cruise (see Appendix A4) and concluded that the calculated $\mathrm{CD} 139 \mathrm{C}_{T}$ data should be reduced by $4 \mu \mathrm{mol} \mathrm{kg}^{-1}$.

\section{Back-calculation methods to estimate $\mathrm{C}_{\mathrm{ANT}}$}

The following sections provide a basic description of the different back-calculation methodologies used in this comparison exercise:

1) $\Delta C^{*}$ approach: developed by Gruber et al. (1996) and applied specifically to the Indian Ocean by Sabine et al. (1999, hereinafter SAB99);

2) IPSL approach: an improved version of the backcalculation technique proposed by Lo Monaco et al. (2005a, hereinafter LM05) for the Southern Ocean;

3) $\Delta C^{*}$ combined $\left(\Delta C^{*} \mathrm{Comb}\right)$ : several improvements were suggested to the $\Delta \mathrm{C}^{*}$ approach in the North Atlantic by Pérez et al. (2002), some of them can be also applied in the Indian Ocean.

\section{1 $\Delta \mathbf{C}^{*}$ (SAB99) approach}

$C_{\mathrm{ANT}}(\mathrm{SAB} 99)=C_{T}-\Delta \mathrm{C}_{T}^{\text {bio }}-\mathrm{C}_{T}^{280}-\Delta \mathrm{C}_{T}^{\mathrm{dis}}$

where $\mathrm{C}_{T}$ represents $\mathrm{C}_{T}$ measurements, $\Delta \mathrm{C}_{T}^{\text {bio }}$ reflects the change in $\mathrm{C}_{T}$ due to biological activity, $\mathrm{C}_{T}^{280}$ denotes the $\mathrm{C}_{T}$ in equilibrium with the pre-industrial atmosphere and $\Delta \mathrm{C}_{T}^{\mathrm{dis}}$ reflects the air-sea $\mathrm{CO}_{2}$ disequilibrium when water masses are formed. The first three terms make up the quasiconservative tracer $\Delta C^{*}\left(\Delta C^{*}=C_{T}-\Delta C_{T}^{\text {bio }}-C_{T}^{280}\right)$, which reflects both the anthropogenic signal and the air-sea $\mathrm{CO}_{2}$ disequilibrium $\left(\Delta \mathrm{C}^{*}=\mathrm{C}_{\mathrm{ANT}}+\Delta \mathrm{C}_{T}^{\mathrm{dis}}\right)($ Gruber et al., 1996).

$\Delta \mathrm{C}_{T}^{\text {bio }}=\mathrm{AOU} / \mathrm{R}_{C}+\frac{1}{2} \times\left(\mathrm{TA}-\mathrm{TA}^{0}+\mathrm{AOU} / \mathrm{R}_{N}\right)$

$-106 / 104 \times \mathrm{N} *$

where: AOU is the Apparent Oxygen Utilization (oxygen saturation (Benson and Krause, 1984) minus measured oxygen); $\mathrm{TA}^{0}$ is preformed $\mathrm{TA} ; \mathrm{R}_{C}$ and $\mathrm{R}_{N}$ are stoichiometric ratios $\mathrm{C} / \mathrm{O}_{2}$ and $\mathrm{N} / \mathrm{O}_{2}$ according to Anderson and Sarmiento (1994); $\mathrm{N}^{*}$ is a quasi-conservative tracer used to identify nitrogen excess or deficits relative to phosphorus. $\mathrm{N}^{*}$ values are converted to carbon with a denitrification carbon to nitrogen ratio of 106:-104 (Gruber and Sarmiento, 1997).

$\mathrm{TA}^{0}=378.1+55.22 \times \mathrm{S}+0.0716 \times \mathrm{PO}-1.236$

$\mathrm{N} *=0.87 \times(\mathrm{N}-16 \times \mathrm{P}+2.90)$

where: $\mathrm{S}$ is salinity; $\mathrm{PO}$ a conservative tracer $\left(\mathrm{PO}=\mathrm{O}_{2}+170 \times \mathrm{P}\right.$; Broecker, 1974); $\theta$ is potential temperature; $\mathrm{P}$ and $\mathrm{N}$ are the phosphate and nitrate concentrations, respectively.
$\mathrm{C}_{T}^{280}$ was obtained from thermodynamic equations of $\mathrm{C}_{T}$ as a function of preformed alkalinity for a pre-industrial partial pressure of $\mathrm{CO}_{2}\left(p \mathrm{CO}_{2}\right)$ of $280 \mathrm{ppm}$ (Gruber et al., 1996). In order to keep the definition of $\Delta C^{*}$ conservative, Gruber et al. (1996) linearized $C_{T}^{280}$ about the mean values of temperature, salinity and alkalinity observed in surface waters of the Atlantic Ocean, which yield an uncertainty of $4 \mu \mathrm{mol} \mathrm{kg}^{-1}$. SAB99 used the linearized formula obtained by Gruber et al. (1996) for the Atlantic Ocean given below:

$\mathrm{C}_{T}^{280}=2072-8.982 \times(\theta-9)-4.931 \times$

$(\mathrm{S}-35)+0.842 \times\left(T A^{0}-2320\right)$

Finally, SAB99 obtained $\Delta \mathrm{C}_{T}^{\mathrm{dis}}$ following the technique proposed by Gruber et al. (1996): i) for water masses younger than 40 years they used the $\Delta C^{*} \tau$ method $\left[\Delta \mathrm{C}^{*} \tau=\mathrm{C}_{T}-\Delta \mathrm{C}_{T}^{\text {bio }}-\mathrm{C}_{T}^{\tau}\right.$, where $\mathrm{C}_{T}^{\tau}$ is the $\mathrm{C}_{T}$ in equilibrium with the atmospheric $\mathrm{CO}_{2}$ at the time of water mass formation: $\mathrm{t}_{\mathrm{form}}=\mathrm{t}_{\mathrm{obs}}-\tau$, the water mass age $\tau$ being calculated from CFC-12 ages; the atmospheric time history for $\mathrm{CO}_{2}$ is taken from the South Pole SIO station (Keeling and Whorf, 2005)]; ii) for old waters with CFC- 12 concentrations lower than $0.005 \mathrm{pmol} \mathrm{kg}^{-1}$ they assumed no anthropogenic carbon so that $\Delta \mathrm{C}_{T}^{\mathrm{dis}}$ is given by $\Delta \mathrm{C}^{*}$ mean values; and iii) for waters older than 40 years with significant CFC-12 concentrations they used a combination of the two methods mentioned above. Values of $\Delta \mathrm{C}_{T}^{\mathrm{dis}}$ were determined along $\sigma_{\theta}$ intervals. One of the main assumptions of this method is that the effective disequilibrium values remain more or less constant within the outcrop region of each isopycnal surface. Consequently, we have used SAB99 disequilibrium values on this work, using their Tables 2 and 3.

The $\Delta \mathrm{C}^{*}$ approach assumes that:

1. total alkalinity is not significantly affected by the $\mathrm{CO}_{2}$ increase in the atmosphere;

2. the effective $\mathrm{CO}_{2}$ air-sea disequilibrium has stayed constant within the outcrop region of a particular isopycnal surface;

3. water transport is mainly along isopycnal surfaces;

4. preformed $\mathrm{O}_{2}$ is in equilibrium with the atmosphere;

5. the decomposition of organic matter follows a constant Redfield relationship.

See Matsumoto and Gruber (2005) for a discussion of these assumptions.

\subsection{IPSL approach}

$C_{\mathrm{ANT}}(\mathrm{IPSL})=\mathrm{C}_{T}-\Delta \mathrm{C}_{T}^{\text {bio }}-\mathrm{C}_{T}^{0, \text { obs }}-\Delta \mathrm{C}_{T}^{0, \mathrm{REF}}$

where: $\Delta \mathrm{C}_{T}^{\text {bio }}$ reflects the change in $\mathrm{C}_{T}$ due to biological activity, calculated similarly though not identically as for 
the $\Delta \mathrm{C}^{*}$ approach (see Eq. 7 below); $\mathrm{C}_{T}^{0, \text { obs }}$ denotes the preformed $\mathrm{C}_{T}$ at the time of observation (here 2002); and $\Delta \mathrm{C}_{T}^{0, R E F}$ is a reference level defined as $\Delta \mathrm{C}_{T}^{0}$ mean value calculated in an old water mass where no $\mathrm{C}_{\mathrm{ANT}}$ is expected $\left(\Delta \mathrm{C}_{T}^{0}=\mathrm{C}_{T}-\Delta \mathrm{C}_{T}^{\text {bio }}-\mathrm{C}_{T}^{0, \text { obs }}\right)$.

The improvements introduced in $\Delta C_{T}^{\text {bio }}$ calculation by LM05 are i) to account for the oxygen disequilibrium in waters formed under the ice and ii) a better characterization of $\mathrm{TA}^{0}$ by using two different relationships (depending on water mass origin) which were determined using either winter and early spring surface measurements $(0-50 \mathrm{~m})$ or subsurface measurements $(50-150 \mathrm{~m})$ :

$$
\begin{aligned}
& \Delta \mathrm{C}_{T}^{\text {bio }}=\left(\mathrm{O}_{2}-(1-\alpha \times k) \times \mathrm{O}_{2} \mathrm{sat}\right) \times \\
& \left(1 / \mathrm{R}_{C}+0.5 / \mathrm{R}_{N}\right)+\frac{1}{2} \times\left(\mathrm{TA}-\mathrm{TA}^{0}\right)
\end{aligned}
$$

where: $k$ stands for the mixing ratio of ice-covered surface waters determined using an optimum multiparameter method (OMP, see Appendix $\mathrm{B}$ ); and $\alpha$ is the mean $\mathrm{O}_{2}$ undersaturation in ice-covered waters, $12 \%$ as justified in LM05. The stoichiometry term $\left(1 / R_{C}+0.5 / R_{N}\right)$ equals 0.8 following Körtzinger et al. (2001).

Linear equations for the preformed values, $\mathrm{TA}^{0}$ and $\mathrm{C}_{T}^{0 \text {,obs }}$ were obtained from winter and early spring surface data using South Atlantic and Indian ocean data (WOCE (Key et al., 2004) and OISO (Metzl et al., 2006) cruises) for southern origin waters (LM05), and from North Atlantic ocean and Nordic seas subsurface data (WOCE and KNORR cruises) for northern origin waters. The relationships for southern waters are:

$$
\begin{aligned}
& \mathrm{TA}_{\mathrm{S}}^{0}=217.15+59.787 \times \mathrm{S}+0.0685 \times \\
& \mathrm{PO}-1.448 \times \theta ;\left( \pm 5.5 \mu \mathrm{mol} \mathrm{kg}-1, r^{2}=0.96, n=243\right)
\end{aligned}
$$

$\mathrm{C}_{T_{\mathrm{S}}^{0, \mathrm{obs}}}=739.83+42.790 \times \mathrm{S}-0.0439 \times$

$\mathrm{PO}-12.019 \times \theta ;\left( \pm 6.3 \mu \mathrm{mol} \mathrm{kg}{ }^{-1}, r^{2}=0.99, n=428\right)$

The relationships for northern waters are:

$\mathrm{TA}_{N}^{0}=804.6+42.711 \times \mathrm{S}+1.265 \times \theta ;$

$\left( \pm 9.3 \mu \mathrm{mol} \mathrm{kg}{ }^{-1}, r^{2}=0.92, n=247\right)$

$\mathrm{C}_{T_{\mathrm{N}}^{0, \text { obs }}}=1631.6+10.69 \times \mathrm{S}+0.306 \times \mathrm{NO} ;$

$\left( \pm 9.2 \mu \mathrm{mol} \mathrm{kg}^{-1}, r^{2}=0.79, n=364\right)$

where all the terms have been previously defined. The stoichiometry terms $\left(\mathrm{R}_{N}\right.$ and $\left.\mathrm{R}_{P}\right)$ are taken from Körtzinger et al. (2001).
In the subtropical Indian Ocean the only contribution of northern water is North Atlantic Deep Water (NADW) entering the Indian Ocean south of Africa. The mixing ratio of NADW ( $\mathrm{k}_{\mathrm{NADW}}$ ) is obtained from the OMP analysis, the southern water contribution is then given by $1-\mathrm{k}_{\text {NADW. }}$. The expressions used to estimate the preformed values are as follows:

$$
\begin{aligned}
& \mathrm{TA}^{0}=k_{\mathrm{NADW}} \times \mathrm{TA}_{N}^{0}+\left(1-k_{\mathrm{NADW}}\right) \times \mathrm{TA}_{\mathrm{S}}^{0} \\
& \mathrm{C}_{T}^{0, \text { obs }}=k_{\mathrm{NADW}} \times \mathrm{C}_{T_{N}^{0, \text { obs }}}+\left(1-k_{\mathrm{NADW}}\right) \times \mathrm{C}_{T_{\mathrm{S}}^{0, \text { obs }}}
\end{aligned}
$$

$\Delta \mathrm{C}_{T}^{0, \mathrm{REF}}$ is calculated using a water mass formed before the industrial revolution which serves as a reference (details are given in LM05). In 2002 along the CD139 cruise, NADW was detected on the Mozambique Basin between 2000 and $4000 \mathrm{~m}$ (Fig. B2) as a salinity maximum, old enough to be $\mathrm{C}_{\mathrm{ANT}}$ free, where no $\mathrm{CFC}-12$ or $\mathrm{CCl}_{4}$ were found (Fig. $5 \mathrm{~b}$ ).

Following LM05 and using data with a contribution of NADW higher than $50 \%$, the mean value for $\Delta \mathrm{C}_{T}^{0, \mathrm{REF}}$ is $-58.6 \pm 1.4 \mu \mathrm{mol} \mathrm{kg}^{-1}$ (37 samples). This value is not significantly different from that used by Vázquez-Rodríguez et al. (2009) when using the IPSL method in the whole Atlantic Ocean.

The IPSL approach assumes that:

1. total alkalinity is not significantly affected by the $\mathrm{CO}_{2}$ increase in the atmosphere;

2. the oxygen disequilibrium in ice-covered waters is constant in space and time;

3. the decomposition of organic matter follows a constant Redfield relationship.

\section{3 $\Delta \mathbf{C}^{*}$ combined approach}

$\mathrm{C}_{\mathrm{ANT}}(\mathrm{Comb})=\mathrm{C}_{T}-\Delta \mathrm{C}_{T}^{\text {bio }}-\mathrm{C}_{T}^{280}-\Delta \mathrm{C}_{T}^{\mathrm{dis}}$

where: $\Delta \mathrm{C}_{T}^{\text {bio }}$ is calculated as in SAB99 (Sect. 3.1); $\mathrm{TA}^{0}$ is calculated following the LM05 approach (Sect. 3.2, Eq. 12); and $\mathrm{C}_{T}^{280}$ is calculated as a function of $\theta, \mathrm{S}, \mathrm{TA}^{0}$ and $p \mathrm{CO}_{2}^{280}$ using the constants from Lueker et al. (2000) instead of the linearized Eq. (5). $p \mathrm{CO}_{2}^{280}$ includes the water vapour correction term as indicated by Pérez et al. (2002). $\Delta C_{T}^{\text {dis }}$ is calculated as in SAB99 (Sect. 3.1) but using the corresponding modified $\mathrm{TA}^{0}$ and $\mathrm{C}_{T}^{280}$.

The $\Delta \mathrm{C}^{*}$ combined approach shares the same assumptions as $\Delta \mathrm{C}^{*}$ described above.

Regarding the uncertainty of each method a detailed error assessment is given in the corresponding publications. Typical uncertainties converge to a common value of 6 $10 \mu \mathrm{mol} \mathrm{kg}^{-1}$. 


\section{TrOCA method}

This carbon-based method uses the semi-conservative parameter TrOCA (Tracer combining Oxygen, inorganic Carbon and total Alkalinity). A detailed description of the TrOCA approach is given in Touratier and Goyet (2004a, b) and further improvements in Touratier et al. (2007):

$$
\begin{aligned}
& \mathrm{C}_{\mathrm{ANT}}(\operatorname{TrOCA})=\left(\operatorname{TrOCA}-\operatorname{TrOCA}^{0}\right) / a \\
& \operatorname{TrOCA}=\mathrm{O}_{2}+a \times\left(\mathrm{C}_{T}-0.5 \times \mathrm{TA}\right) \\
& \operatorname{TrOCA}^{0}=e^{(b+c \times \theta+d / \mathrm{TA} \wedge 2)}
\end{aligned}
$$

where $\mathrm{C}_{\mathrm{ANT}}$ is calculated as the difference between current (Eq. 15b) and pre-industrial TrOCA (TrOCA ${ }^{0}$, Eq. 15c) according to Touratier et al. (2007) divided by a stoichiometric coefficient, $a$. $\operatorname{TrOCA}^{0}$ and the coefficient $a$ were adjusted using $\Delta^{14} \mathrm{C}$ and CFC-11 data to identify water masses with particular ages. The parameter values used are $a=1.279 \pm 7.3 \times 10^{-3}$, $b=7.511 \pm 5.2 \times 10^{-3}, c=-1.087 \times 10^{-2} \pm 2.5 \times 10^{-5 \circ} \mathrm{C}^{-1}$ and $d=-7.81 \times 10^{5} \pm 2.9 \times 10^{4}\left(\mu \mathrm{mol} \mathrm{kg}{ }^{-1}\right)^{2}$.

The TrOCA approach assumes that: below the mixed layer, the decomposition of organic matter follows a constant Redfield relationship and today's air-sea $\mathrm{CO}_{2}$ disequilibrium is the same as in pre-industrial times. No explicit assumptions are made about the preformed values for alkalinity or inorganic carbon. The estimated uncertainty for the TrOCA approach to estimate $\mathrm{C}_{\mathrm{ANT}}$ is about $6 \mu \mathrm{mol} \mathrm{kg}{ }^{-1}$ (Touratier et al., 2007).

\section{$5 \quad$ TTD method}

The Transit Time Distribution (TTD) method is a formal way of describing the history of the individual components (e.g. water molecules) making up a water sample. For any water sample collected at a given location in the ocean, the various water molecules making up the sample will have travelled different pathways to reach that point, with each molecule having its own "age", i.e. time since it was last in contact with the atmosphere. The distribution of all these ages comprises the TTD of a water sample. Once the TTD is established, in principle the concentration of any other passive tracer (e.g. anthropogenic $\mathrm{CO}_{2}$ ) entering the ocean at the surface can be calculated. In several previous studies (following Waugh et al., 2004; Waugh et al., 2006) the TTDs have been assumed to have an inverse Gaussian shape, with the mean age $(\Gamma)$ and the width $(\Delta)$ of the TTD as fundamental descriptors. In these studies and in this work it is also assumed that the ratio $\Delta / \Gamma=1$, i.e. the mean age is equal to the width of the TTD. This is found to be a realistic assumption of the relation between advective and diffusive transport in the Ocean (Waugh et al., 2004, 2006; Tanhua et al., 2008).
The TTD method used here to estimate $\mathrm{C}_{\mathrm{ANT}}$ concentrations is that described by Waugh et al. $(2004,2006)$. We assume that $\mathrm{C}_{\mathrm{ANT}}$ is an inert passive tracer (with a well known atmospheric history), and that the transfer of inorganic carbon from the atmosphere to the ocean can be determined by using the empirical relations between surface salinity and alkalinity (e.g. Brewer et al., 1986) and the inorganic carbon chemistry. Thus, with only observations of salinity, temperature and tracer, the oceanic $\mathrm{C}_{\mathrm{ANT}}$ input function for each water sample can be determined. We used CFC-12 data to determine the TTDs of the water samples using the timedependent saturation described in Tanhua et al. (2008) and we have assumed that the disequilibrium of carbon between the atmosphere and the surface ocean did not change during the last few hundred years. The latter assumption is possibly the single largest single source of error for the $\mathrm{C}_{\mathrm{ANT}}$ TTD calculation; other sources of errors are discussed in Waugh et al. (2006) and Tanhua et al. (2008). For instance, uncertainties in the $\Delta / \Gamma$ ratio propagates to uncertainties in $C_{\text {ANT }}$ TTD and is dependent on CFC concentrations and $\Delta / \Gamma$ ratio; the

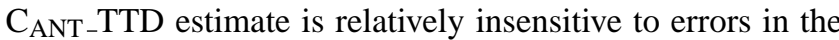
$\Delta / \Gamma$ ratio for CFC-12 levels higher than $0.5-0.6 \mathrm{pmol} \mathrm{kg}^{-1}$ and to errors in the $\Delta / \Gamma$ ratio for moderate to large mixing $(\Delta / \Gamma \geq 0.75)$. The TTD method is also sensitive to uncertainties on the CFC saturation state at the time of water mass formation; the biasing effect is larger for CFC- 12 concentrations larger than about $450 \mathrm{ppt}$ due to the low atmospheric increase rate in recent times (Tanhua et al., 2008).

\section{General ocean model $\mathrm{C}_{\mathrm{ANT}}$}

The model used here is OCCAM (Ocean Circulation and Climate Advanced Modelling), a global, medium-resolution, primitive equation ocean general circulation model (Marsh et al., 2005, describe a high-resolution version). OCCAM's vertical resolution is 66 levels $(5 \mathrm{~m}$ thickness at the surface, $200 \mathrm{~m}$ at depth), with a horizontal resolution of typically 1 degree. OCCAM's prognostic variables are temperature, salinity, velocity and free-surface height. The model includes an Elastic Viscous Plastic sea-ice scheme, a K-Profile Parameterization mixed layer and Gent-McWilliams eddy parameterisation. Advection is 4th order accurate, and the model is time-integrated using a forward leapfrog scheme with a $1 \mathrm{~h}$ time-step. Surface fluxes of heat and freshwater are not specified but are calculated empirically using NCEP-derived atmospheric boundary quantities (Large and Yeager, 2004). In this way, simulations are forced for the period January 1958 to December 2004, and repeat cycles of this 47-year forcing are used to spin-up the model. OCCAM incorporates a NPZD (Nitrate Phytoplankton Zooplankton Detritus) plankton ecosystem model (Oschlies, 2001; Yool et al., 2007) which drives the biogeochemical cycles of nitrogen, carbon, oxygen and alkalinity. Air-sea fluxes of $\mathrm{CO}_{2}$ and $\mathrm{CFC}$ tracers (for watermass age) make use of the protocols developed for 

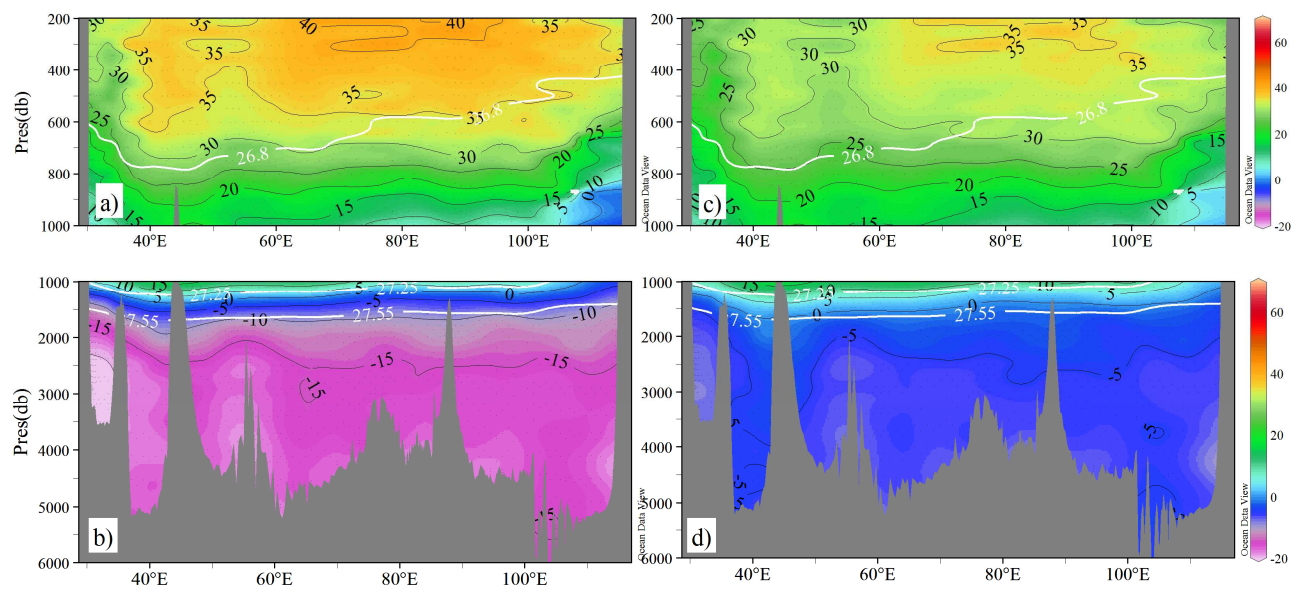

Fig. 2. $\Delta \mathrm{C}^{*}\left(\mu \mathrm{mol} \mathrm{kg}^{-1}\right)$ vertical distribution along the CD139 section estimated according to SAB99 (a, b) and the combined method (c, d). White lines correspond to $\sigma_{\theta}$ isopycnals used as references.

the OCMIP-2 project (see Dutay et al., 2002; Matsumoto et al., 2004). The simulation shown here was initialised from rest using physical and biogeochemical climatological fields (Conkright et al., 2002; Key et al., 2004), and underwent an initial 47 year cycle of pre-industrial spin-up. After this, the model used three 47 year cycles to simulate the period 1864 to 2004, during which model atmospheric $p \mathrm{CO}_{2}$ followed the historical record. A duplicate $\mathrm{C}_{T}$ tracer that was not exposed to this record was used to both separate the natural cycle of carbon from the anthropogenic perturbation and control for simulation drift.

\section{Results}

\section{1 $\Delta \mathbf{C}^{*}$ distributions}

$\Delta C^{*}$ is calculated here by two methods: SAB99 (Sect. 3.1) and a combined (Comb) approach (Sect. 3.4). The difference between these stems from their estimations of $\mathrm{TA}^{0}$, included in the $\Delta \mathrm{C}_{T}^{\text {bio }}$ term, and $\mathrm{C}_{T}^{280}$, also dependent on $\mathrm{TA}^{0}$. In $\mathrm{SAB} 99, \mathrm{TA}^{0}$ is taken from Eq. (3) and adjusted as a function of Indian Ocean data shallower than 60 dbar. $\mathrm{C}_{T}^{280}$ is calculated from Eq. (5) which was obtained by Gruber et al. (1996) for the Atlantic Ocean. In the case of the combined approach, $\mathrm{TA}^{0}$ discerns waters with southern and northern origins, taking into account the mixing, and $\mathrm{C}_{T}^{280}$ is obtained using a thermodynamic formula to calculate $\mathrm{C}_{T}^{280}$ as a function of $p \mathrm{CO}_{2}^{280}$ and $\mathrm{TA}^{0}$ (see Sect. 3.3). These details in the $\Delta \mathrm{C}^{*}$ calculation have a significant impact on estimates of $\mathrm{C}_{\mathrm{ANT}}$. Figure 2 shows the vertical distributions of $\triangle C^{*} \mathrm{SAB} 99$ and $\Delta C^{*}$ Comb: below $1000 \mathrm{dbar} \Delta \mathrm{C}^{*} \mathrm{SAB} 99$ is lower, more negative, than the $\Delta \mathrm{C}^{*} \mathrm{Comb}$ by about $10 \mu \mathrm{mol} \mathrm{kg}{ }^{-1}$, with maximum negative differences (SAB99-Combined $\Delta C^{*}$ ) found in the NADW core (Fig. 3). This difference inverts in the upper $1000 \mathrm{dbar}, \Delta \mathrm{C}^{*} \mathrm{Comb}$ is higher by up to
$5 \mu \mathrm{mol} \mathrm{kg}^{-1}$ (Fig. 2 and 3). A closer look at the contribution from $\Delta \mathrm{C}_{T}^{\text {bio }}$ and $\mathrm{C}_{T}^{280}$ to the $\Delta \mathrm{C}^{*}$ difference shows (Fig. 3) that the $\mathrm{C}_{T}^{280}$ is primarily responsible for the differences between SAB99 and Comb $\Delta C^{*}$ in the upper 1000 dbar. Here the mean \pm STD $\mathrm{C}_{T}^{280}$ contribution to the mean \pm STD $\Delta \mathrm{C}^{*}$ difference is $-4.5 \pm 1.9$ compared to $3.1 \pm 2.5$; while below 1000 dbar both terms have a similar contribution, $4.7 \pm 1.8$ from $C_{T}^{280}$ and $4.2 \pm 1.7 \mu \mathrm{mol} \mathrm{kg}^{-1}$ from $\Delta C_{T}^{\text {bio }}\left(\Delta C^{*}\right.$ difference $-8.9 \pm 2.4 \mu \mathrm{mol} \mathrm{kg}^{-1}$ ). This result points to the importance of using accurate approximations for preformed values, especially where mixing of extreme origin water masses is occurring, and also that the complete thermodynamic equation for $\mathrm{C}_{T}^{280}$ should be used in preference to linearized functions obtained for different basins.

\section{2 $\Delta \mathbf{C}_{T}^{\text {dis }}$ values}

The next step in the $\Delta C^{*}$ back-calculation approach is to obtain the $\Delta \mathbf{C}_{T}^{\text {dis }}$ values by $\sigma_{\theta}$ intervals (Sect. 3.1). $\Delta \mathbf{C}_{T}^{\text {dis }}$ values should ideally be calculated along a wide regional or age range, therefore, databases with ample coverage are needed. These also enable the identification and treatment of different water mass end-members. The database used by SAB99 covered the whole Indian Ocean, where most of the waters below the mixed layer have a southern origin except intermediate waters formed in the Arabian Sea. Taking this into account and the assumption of a constant $\Delta \mathrm{C}_{T}^{\mathrm{dis}}$ with time we used SAB99 $\Delta \mathrm{C}_{T}^{\text {dis }}$ values. No Arabian Sea endmember was considered. However, to check the impact of using different $\mathrm{TA}^{0}$ and $\mathrm{C}_{T}^{280}$ approximations on $\Delta \mathrm{C}_{T}^{\mathrm{dis}}$ we recalculated new values for the effective air-sea disequilibrium: using our own CD139 data set for $\Delta C^{*}$ and $\Delta C^{*} \tau$ i) from Sect. 3.1, the SAB99 approach; and ii) from Sect. 3.3, the combined approach. Figure 4 presents the three $\Delta \mathrm{C}_{T}^{\text {dis }}$ set of values (original SAB99 values and those obtained from our data) by $\sigma_{\theta}$ intervals. $\Delta \mathbf{C}_{T}^{\mathrm{dis}}$ values calculated with our 


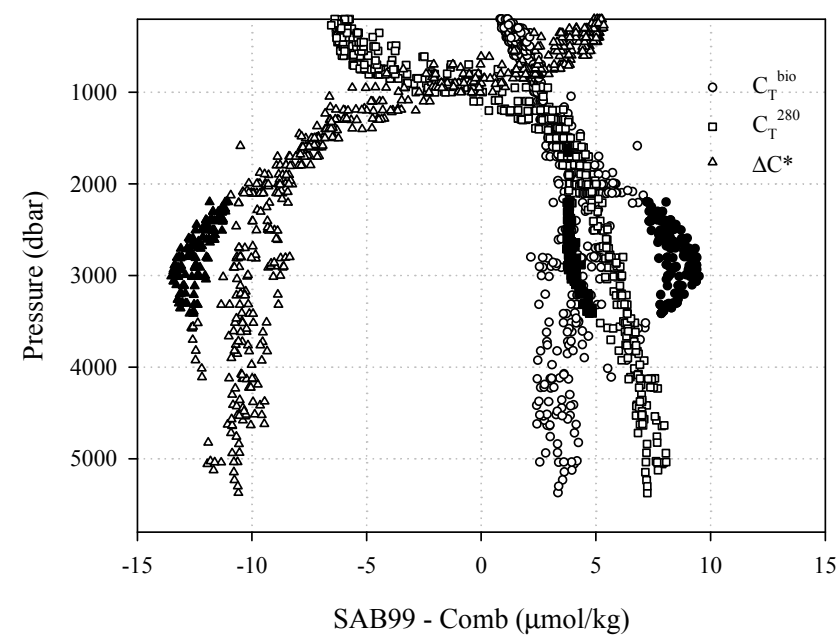

Fig. 3. Difference in $\Delta C^{*}$ (triangles), the biological term contribution, $\Delta \mathrm{C}_{T}^{\text {bio }}$ (diamonds), and the pre-industrial term, $\mathrm{C}_{T}^{280}$ (squares), estimated with the SAB99 and Comb. methods. The NADW core is highlighted in black. All in $\mu \mathrm{mol} \mathrm{kg}^{-1}$. For clarity every 4th sample was represented.

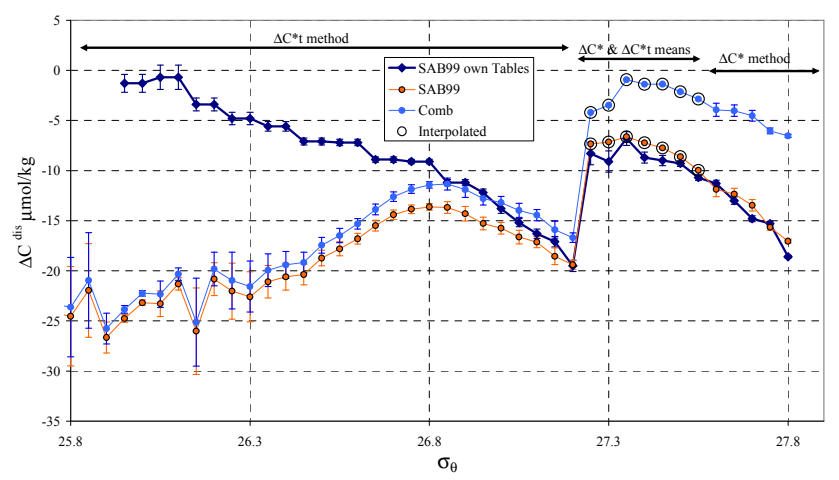

Fig. 4. Air-sea $\mathrm{CO}_{2}$ disequilibrium $\left(\mu \mathrm{mol} \mathrm{kg}^{-1}\right)$ by $\sigma_{\theta}$ density intervals. Blue points correspond to the values taken directly from SAB99 work, light blue and orange points correspond to the values estimated using the CD139 biogeochemical data, following SAB99 (orange) and combined (light blue) methods. Interpolated points are highlighted with black open circles.

own data for $\sigma_{\theta}<26.8$ should be disregarded due to the reduced density of samples with these characteristics (situated above 600 dbar along the CD139 section). Data between $27.55>\sigma_{\theta}>27.25$ should be weighted means between $\Delta C^{*}$ and $\Delta \mathrm{C}^{*} \tau$; however, our own data has no points that fulfil the conventions in SAB99, and consequently they were linearly interpolated. $\Delta \mathrm{C}_{T}^{\mathrm{dis}}$ values between $27.2>\sigma_{\theta}>26.8$ are obtained from $\Delta C^{*} \tau$ values and they show a clear consistency between the SAB99 (SAB99 Tables and our own data) and combined (for our data) approaches. For the $\Delta C^{*} \tau$ calculation the main source of error is the estimation of the age, calculated equally on the three $\Delta C^{*} \tau$ approaches, here the effect of a different preformed $\mathrm{TA}^{0}$ (for the combined method) is minor (Matsumoto and Gruber, 2005). In deep layers, $\sigma_{\theta} \geq 27.6$, the $\Delta \mathrm{C}_{T}^{\mathrm{dis}}$ disagreement is obvious between the two SAB99 methods and the combined one, the two SAB99 estimations coincide as expected, with values from -11 to $-18.6 \mu \mathrm{mol} \mathrm{kg}^{-1}$ while with the combined approach, $\Delta \mathrm{C}_{T}^{\text {dis }}$ varies from -4 to $-6.5 \mu \mathrm{mol} \mathrm{kg}^{-1}$. This difference stems from the $\mathrm{C}_{T}^{280}$ and $\mathrm{TA}^{0}$ (Fig. 3), included in the $\Delta \mathrm{C}^{*}$ formula.

\section{3 $\mathrm{C}_{\mathrm{ANT}}$ distributions}

The vertical pCFC-12, $\mathrm{pCCl}_{4}$ and $\mathrm{C}_{\mathrm{ANT}}$ distributions along with some reference neutral density levels are shown in Figs. 5 and 6. In deep layers below $\gamma=27.7$, no $\mathrm{C}_{\mathrm{ANT}}$ is expected according to CFC-12 levels (Fig. 5a), here the $\Delta C^{*}$ method is used to calculate $\Delta \mathrm{C}_{T}^{\mathrm{dis}}$, and $\mathrm{C}_{\mathrm{ANT}} \mathrm{SAB} 99$ values are practically null, $0 \pm 3 \mu \mathrm{mol} \mathrm{kg}{ }^{-1}$, which is less than the limit of detection of the method. However, according to $\mathrm{CCl}_{4}$ levels $\mathrm{C}_{\mathrm{ANT}}$ is expected in this layer. In this sense, $\mathrm{C}_{\mathrm{ANT}}$ IPSL and TrOCA estimates range from 0 to $10 \mu \mathrm{mol} \mathrm{kg}^{-1}$, with slightly lower values estimated by the TTD method and values below $5 \mu \mathrm{mol} \mathrm{kg}^{-1}$ simulated by OCCAM. The western NADW core (Fig. B2) between 2000-3000,dbar presents consistently negative values for the SAB99 method (Fig. 5b). A combination of processes leads to these negative values: predominantly the erroneous estimation of $\mathrm{TA}^{0}$ in the biological correction, and also the application of a $\Delta \mathrm{C}_{T}^{\text {dis }}$ too negative and more representative of southern waters, dominant in the rest of the section. The TrOCA, IPSL and TTD methods do detect this core while the OCCAM results are quite homogeneous for deep waters (Figs. 5 and 6). The influence of water formed under ice is clearly detected by the $\mathrm{C}_{\mathrm{ANT}}$-IPSL method below 4000 dbars (Fig. B2) where $\mathrm{C}_{\mathrm{ANT}}$ slightly increases towards the bottom (Fig. 5f) as $\mathrm{pCCl}_{4}$ does (Fig. 5b). The TrOCA and TTD methods also show this slight increase (Fig. 6b, d) despite being based on completely different assumptions.

In the region between roughly 1000 and $1500 \mathrm{dbar}$ the SAB99 method uses weighted means of $\Delta C^{*} \tau$ and $\Delta C^{*}$ to estimate $\Delta \mathrm{C}_{T}^{\mathrm{dis}}$ (Fig. 4), and a steep gradient in $\mathrm{C}_{\mathrm{ANT}}$ is detected here (Fig. 5c), with a clear discontinuity with pressure not apparent in any of the other approaches or physical, biogeochemical or tracer variables (not shown). Similar results were found by Waugh et al. (2006) in the Atlantic Ocean. The other $\mathrm{C}_{\mathrm{ANT}}$ methods with a smoother $\mathrm{C}_{\mathrm{ANT}}$ gradient in this pressure range point to a deeper penetration of $\mathrm{C}_{\mathrm{ANT}}$ below the AAIW limit.

In thermocline waters, upper $1000 \mathrm{dbars,}$ all methods, except TTD, show $\mathrm{C}_{\mathrm{ANT}}$ values increasing eastwards, near to the formation region of SAMW (McDonagh et al., 2005). Although the distributions are similar, absolute values differ as will be commented using Fig. 7.

Figure 7 shows the mean \pm STD vertical $C_{\text {ANT }}$ profile difference referred to SAB99. Any of the regional plots show a sharp change around 1300 dbar due to the discontinuity in 

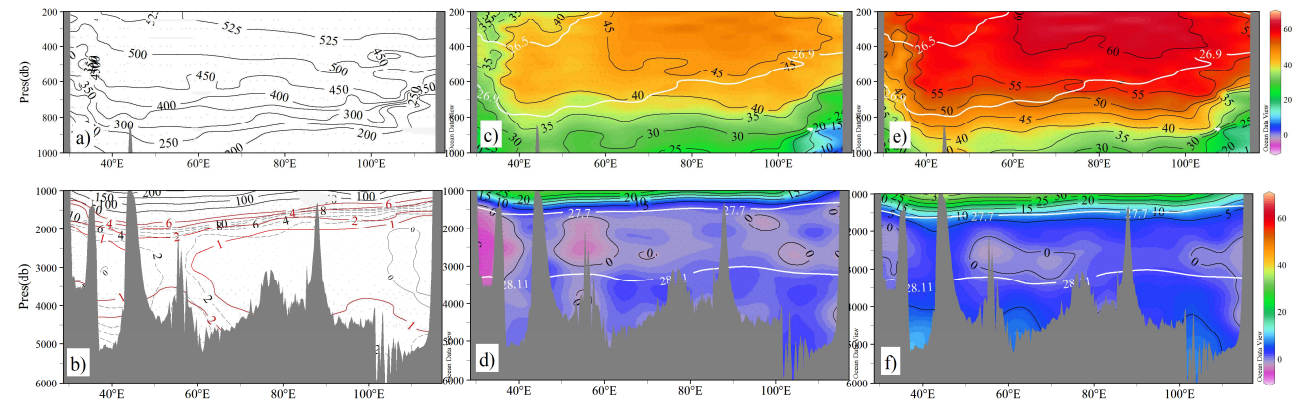

Fig. 5. Vertical distribution along the CD139 section for pCFC-12 (ppt) (a); pCFC-12 (note the different scale on dashed lines) and pCCl 4 (red lines) (b); $\mathrm{C}_{\mathrm{ANT}}\left(\mu \mathrm{mol} \mathrm{kg}{ }^{-1}\right)$ using the SAB99 (c, d) and IPSL (e, f) methods. White lines correspond to neutral density layers, separating water masses.

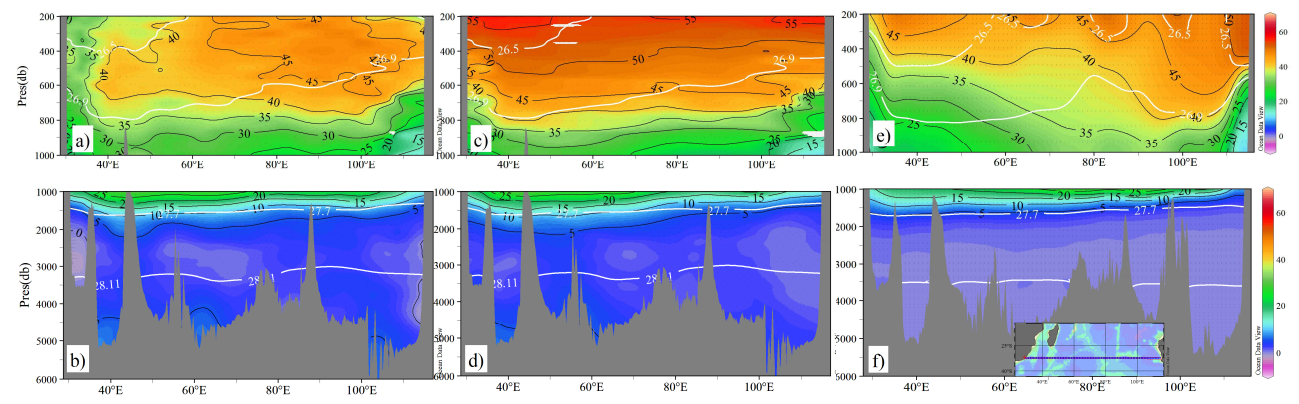

Fig. 6. Vertical distribution along the CD139 section for $\mathrm{C}_{\mathrm{ANT}}\left(\mu \mathrm{mol} \mathrm{kg}{ }^{-1}\right)$ from the TrOCA (a, b); TTD (c, d) and OCCAM (e, f) approaches. White lines correspond to neutral density layers, separating water masses.
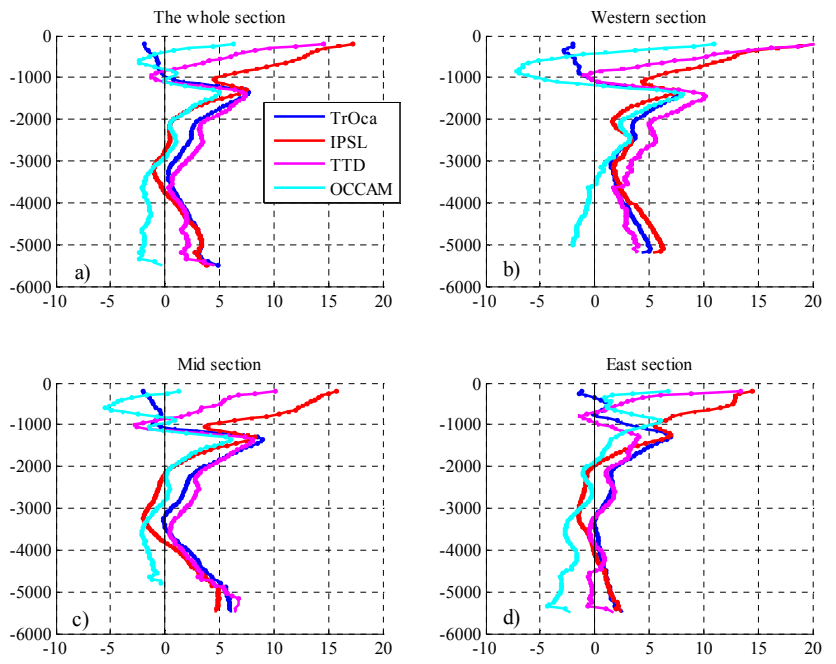

Fig. 7. Mean \pm STD $C_{\text {ANT }}$ differences $\left(\mu \mathrm{mol} \mathrm{kg}^{-1}\right)$ between any

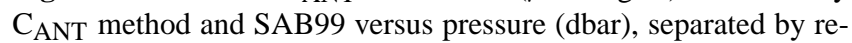
gions: (a) whole section, (b) western (St. up to 59, see Fig. 1), (c) middle (St. 60-109) and (d) eastern $($ St. $\geq 110)$ regions.

$\mathrm{C}_{\mathrm{ANT}} \mathrm{SAB} 99$ where all the methods yield higher $\mathrm{C}_{\mathrm{ANT}}$ values compared to SAB99 up to a maximum of $8 \mu \mathrm{mol} \mathrm{kg}-1$ with the TrOCA method in the middle part of the section
(Fig. 7c), where the salinity minimum is clearly noted. Surprisingly, the IPSL, TrOCA and TTD differences have similar values and distributions below $3500 \mathrm{dbar}$, with consistently increasing $\mathrm{C}_{\mathrm{ANT}}$ values towards the bottom, especially in the western and central portion of the section (Fig. 7b, c), where younger $\mathrm{AABW}$ arrives at the section from the Weddell Sea. In the upper $1000 \mathrm{dbar}$, TrOCA and SAB99 are practically in agreement, while OCCAM presents lower values compared to SAB99 especially in the western part of the section (Fig. 7b), and TTD differences continuously increase towards the surface and reach up to $15 \mu \mathrm{mol} \mathrm{kg}^{-1}$. In this depth range, IPSL values are consistently higher compared to any other method. Between 1500 and 3500 dbars, as a whole (Fig. 7a), TrOCA and TTD, compared to SAB99, give higher results than OCCAM and IPSL, but differences arise within regions.

\section{4 $\mathrm{C}_{\mathrm{ANT}}$ inventories}

Studying the $\mathrm{C}_{\mathrm{ANT}}$ specific inventories by water mass domains shows again clear discrepancies and similarities. We took the neutral density layers definition by Robbins and Toole (1997) to define five layers (Fig. 5 or 6): i) surface water, roughly in the upper $200 \mathrm{~m}$; ii) SAMW between 200 and $600 \mathrm{~m}$; iii) AAIW down to $1500 \mathrm{~m}$; iv) deep waters correspond to upper (Indian Deep Water) and lower (Circumpolar 
Table 1. Mean \pm standard deviation $\mathrm{C}_{\mathrm{ANT}}$ specific inventory $\left(\mathrm{molC} \mathrm{m}^{-2}\right)$ by water masses in the subtropical Indian Ocean for the different methods here evaluated. Mean and standard deviation values were obtained randomly modifying the initially calculated single $\mathrm{C}_{\mathrm{ANT}}$ values by $\pm 5 \mu \mathrm{mol} \mathrm{kg}{ }^{-1}$. A set of 100 perturbations were done for the five methods. The standard deviation for each layer is weighted by the layer contribution to the total section area. See text for the acronyms. N/D stands for not determined. Values between brackets correspond to the IPSL method assuming a $100 \%$ oxygen saturation in Eq. (7), $\alpha=0$.

\begin{tabular}{lllllll}
\hline & Upper & SAMW & AAIW & Deep & Bottom & Total* \\
\hline SAB99 & N/D & $8.5 \pm 0.5$ & $8.1 \pm 0.4$ & $0 \pm 0.5$ & $0.3 \pm 0.2$ & $23.9 \pm 2$ \\
IPSL & N/D & $11 \pm 0.7$ & $11 \pm 0.5$ & $0.6 \pm 0.4(0.5 \pm 0.4)$ & $1.2 \pm 0.3(0.0 \pm 0.3)$ & $30.8 \pm 2.5(29.5 \pm 2.5)$ \\
TrOCA & N/D & $8.4 \pm 0.5$ & $9.4 \pm 0.5$ & $1.9 \pm 0.5$ & $1.4 \pm 0.3$ & $28.1 \pm 2.2$ \\
TTD & $7.2 \pm 0.7$ & $9.3 \pm 0.6$ & $9.3 \pm 0.5$ & $2 \pm 0.4$ & $1.3 \pm 0.2$ & $28.9 \pm 2.3$ \\
OCCAM & $6.9 \pm 1.5$ & $9.3 \pm 0.8$ & $7.6 \pm 0.5$ & $0.5 \pm 0.1$ & $0 \pm 0$ & $24.4 \pm 2.8$ \\
\hline
\end{tabular}

* The total specific inventory is calculated as the sum of the SAMW, AAIW, Deep and Bottom contributions plus $7 \mathrm{molC}^{-2}$, i.e., the TTD and OCCAM mean specific inventory for the upper layer.

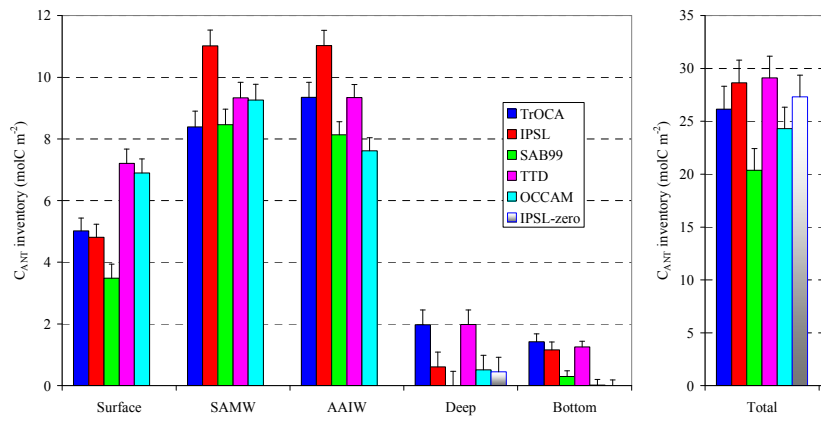

Fig. 8. Mean \pm standard deviation $\mathrm{C}_{\mathrm{ANT}}$ specific inventories $\left(\mathrm{molC} \mathrm{m}{ }^{-2}\right)$ for each water mass layer (see text) and for the whole section on the right. The total specific inventory is calculated as the sum of the SAMW, AAIW, Deep and Bottom contributions plus $7 \mathrm{molC} \mathrm{m}^{-2}$, i.e., the TTD and OCCAM mean specific inventory for the upper layer.

Deep Water, CDW, and NADW on the western end) deep waters; v) bottom water, below roughly $3500 \mathrm{~m}$ with an Antarctic origin. A similar approach was used by McDonagh et al. (2008) to constrain the velocity field along this section.

The initially calculated $\mathrm{C}_{\mathrm{ANT}}$ values are randomly modified by $\pm 5 \mu \mathrm{mol} \mathrm{kg}^{-1}$. A set of 100 perturbations are done for the five methods, finally a mean and standard deviation for the total and layer $\mathrm{C}_{\mathrm{ANT}}$ inventory is calculated, the standard deviation for each layer is weighted by the layer contribution to the total section area. Inventories are shown in Fig. 8 and Table 1.

The SAB99 method estimates the lowest total inventory compared with any other method (Fig. 8, Table 1), even with OCCAM which seems to underestimate $\mathrm{C}_{\mathrm{ANT}}$ in deep and bottom layers (Fig. 7). Discrepancies and similarities arise when inventories are studied by layers. Biological processes in the upper mixed layer (comprised within the surface layer here defined) occurring during the cruise prevent the use of carbon-based methods (SAB99, TrOCA and IPSL), for ex- ample when AOU is negative. These methods neither resolve seasonal variability in the mixed layer. TTD and OCCAM do provide $\mathrm{C}_{\mathrm{ANT}}$ estimates in this layer by circumventing the direct use of biogeochemical variables: TTD relies on $\mathrm{CFC}$ ages that are more precise in upper, younger waters; OCCAM accounts for surface circulation and air-sea $\mathrm{CO}_{2}$ equilibrium, and its upper waters are less affected by uncertainties in model physics and chemistry. Interestingly, the mean specific inventories for the upper layer from TTD and the OCCAM are similar, around $7 \mathrm{molC} \mathrm{m}^{-2}$ (Table 1).

Within the SAMW layer, all methods, except IPSL, agree within \pm 2 molC m$^{-2}$. Within AAIW, IPSL is again high, TTD and TrOCA agree and OCCAM and SAB99 are lower. In deep waters, TTD and TrOCA give similar results significantly higher than any of the other methods, even IPSL. In the bottom layer, TrOCA, IPSL and TTD provide similar results with a significant $\mathrm{C}_{\mathrm{ANT}}$ accumulation in this layer, while OCCAM, SAB99 and Iwithout the oxygen undersaturation correction (IPSL-Zero) show no accumulation.

\section{Discussion}

In most of the comparative studies about $\mathrm{C}_{\mathrm{ANT}}$ estimation in the ocean no clear conclusion about the best method is given because all of them are subject to uncertainties (Coatanoan et al., 2001; Feely, 2001; Hall et al., 2004; LM05; Sabine and Feely, 2001; Wanninkhof et al., 1999; Waugh et al, 2006). In this work with the help of transient tracers, we discuss backcalculation, TrOCA, TTD and OGCM C $\mathrm{ANT}_{\mathrm{AN}}$ methods, trying to assess their strengths and caveats, and finally which may provide the optimal range of estimations.

\subsection{Disequilibrium values on the $\Delta \mathrm{C}^{*}$ method}

The assumptions of the $\Delta C^{*}$ method and its main sources of uncertainty are thoroughly discussed in Matsumoto and Gruber (2005). They conclude that the change in air-sea $\mathrm{CO}_{2}$ 

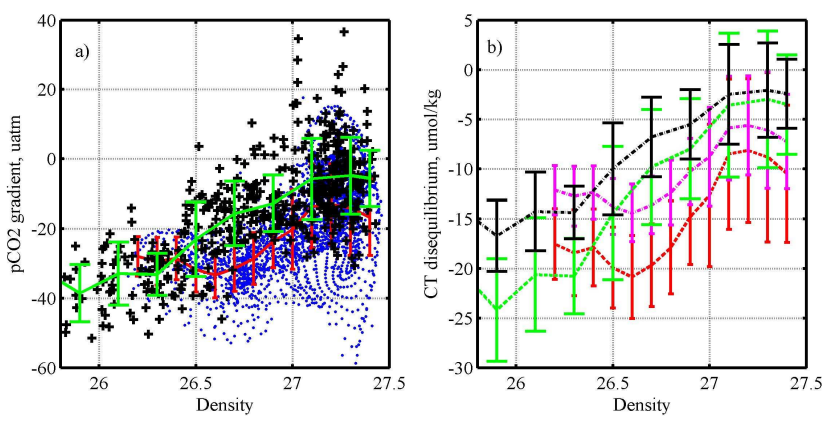

Fig. 9. (a) Late winter-early spring $p \mathrm{CO}_{2}$ gradient (oceanatmosphere, in $\mu \mathrm{atm}$ ) for the Indian ocean south of about $40^{\circ} \mathrm{S}$ by $\sigma_{\theta}$ density from the Takahashi et al. (2002) climatology: raw data (crosses) and mean \pm STD (green line); and empirical data from McNeil et al. (2007): raw data (blue points) and mean \pm STD (red line). (b) Equivalent $\mathrm{C}_{T}$ disequilibrium values calculated from $\Delta \mathrm{C}_{T}^{\mathrm{dis}}=\Delta p \mathrm{CO}_{2} / 359 \times 2020 / \mathrm{R}, 359$ is the mean atmospheric $p \mathrm{CO}_{2}$ and 2020 the mean surface ocean $\mathrm{C}_{T}$ for 1995 , R the Revelle factor, taken as 9 and 13, data from Takahashi et al. (2002) are the black and green lines, data from McNeil et al. (2007) in pink and red.

disequilibrium over time is the single most important contribution to the bias in $\Delta \mathrm{C}^{*}$-based $\mathrm{C}_{\mathrm{ANT}}$ estimations. This method assumes a constant disequilibrium over time. However, the uptake of $\mathrm{C}_{\mathrm{ANT}}$ by the ocean is occurring with an increasing more negative disequilibrium. Consequently, $\mathrm{C}_{\mathrm{ANT}}$ will be overestimated especially in upper and younger waters, causing a positive bias of $5 \mathrm{PgC}$ for the whole ocean (Matsumoto and Gruber, 2005).

Disequilibrium values obtained here from $\Delta C^{*} \tau$ values are equal, as the main source of uncertainty is the age estimate, while biases from using different expressions for $\mathrm{TA}^{0}$ and $\mathrm{C}_{T}^{280}$ cancel out (Fig. 4). When disequilibrium values are calculated from $\Delta \mathrm{C}^{*}$ values in waters with no $\mathrm{C}_{\mathrm{ANT}}$ expected, the disagreement is clear (Fig. 4). Here, $\mathrm{TA}^{0}$ and $\mathrm{C}_{T}^{280}$ estimates do matter (Fig. 3) causing high discrepancies in the final disequilibrium estimate. $\Delta \mathrm{C}_{T}^{\text {dis }}$ estimated by the SAB99 method become more negative with increasing density, while in the combined approach they remain slightly negative and practically constant (Fig. 4).

Which $\Delta \mathrm{C}_{T}^{\text {dis }}$ values are more reasonable with our current knowledge about $\mathrm{CO}_{2}$ dynamics in the upper ocean? The temporal evolution of the disequilibrium can only be obtained from OGCM (e.g., Matear et al., 2005; Matsumoto and Gruber, 2005) or transient tracers transit-time distributions (Hall and Primeau, 2004), while current values of the total (natural plus anthropogenic) disequilibrium can be approximated from measured (Takahashi et al., 2002) or empirical (McNeil et al., 2007) winter-early spring surface ocean-atmosphere gradients in $p \mathrm{CO}_{2}$. The models provide the change in $\Delta \mathrm{C}_{T}^{\mathrm{dis}}$ from the preindustrial era till the 1990s, showing small changes, less than $-5 \mu \mathrm{mol} \mathrm{kg}^{-1}$, in the subtropical Indian ocean, and moderate changes, -5 to
$-10 \mu \mathrm{mol} \mathrm{kg}{ }^{-1}$ south of $60^{\circ} \mathrm{S}$. Consequently, current $p \mathrm{CO}_{2}$ gradients can be compared with $\Delta \mathrm{C}_{T}^{\mathrm{dis}}$ values obtained from the $\Delta \mathrm{C}^{*}$ approach.

Figure 9a shows the mean surface $p \mathrm{CO}_{2}$ gradient sorted by surface density in the winter Indian Ocean from the Takahashi et al. (2002) climatology and the empirical approach by McNeil et al. (2007). Comparing Figs. 4 and 9b discrepancies are evident, first in the shape of the curves and second in the range of values estimated. The discontinuity in $\Delta \mathrm{C}_{T}^{\text {dis }}$ values from SAB99 appears to be an artefact derived from the approximations used in the method.

The mean temporal evolution of the disequilibrium obtained by Matsumoto and Gruber (2005) is consistent with that obtained for the $\sigma_{\theta}=26.5$ isopycnal in the Indian ocean by Hall and Primeau (2004), for 1995 they obtain values from -9 to $-12 \mu \mathrm{mol} \mathrm{kg}^{-1}$ in agreement with Takahashi et al.'s (2002) values $\left(-10\right.$ to $\left.-15 \mu \mathrm{mol} \mathrm{kg}^{-1}\right)$ but less pronounced than McNeil et al.'s (2007) $(-15$ to $-20 \mu \mathrm{mol} \mathrm{kg}^{-1}$ ) (Fig. 9). The SAB99 method yields $-7.1 \pm 0.3 \mu \mathrm{mol} \mathrm{kg}^{-1}$ (Fig. 4). According to this comparison, $\mathrm{C}_{\mathrm{ANT}} \mathrm{SAB} 99$ values in this density range would be too low.

In the case of a shallower isopycnal, $\sigma_{\theta}=25.95, \mathrm{CFC}-12$ ages are only $2-4$ years around $35^{\circ} \mathrm{S}$ in 1995 (Fine et al., 2008). Therefore while its disequilibrium should not be far away from current values, -15 to $-20 \mu \mathrm{mol} \mathrm{kg}^{-1}$ (Fig. 9), SAB99 instead estimates a value of $-1.3 \pm 0.88 \mu \mathrm{mol} \mathrm{kg}^{-1}$. If more negative disequilibrium values are considered, again, $\mathrm{C}_{\mathrm{ANT}} \mathrm{SAB} 99$ estimates would be too low.

Deep waters, around $\sigma_{\theta}=27.4$ have $\Delta C_{T}^{\text {dis }}$ values around $-8 \mu \mathrm{mol} \mathrm{kg}^{-1}$ according to $\mathrm{SAB} 99$, but values around $-3 \mu \mathrm{mol} \mathrm{kg}^{-1}$ by Takahashi et al. (2002) or -5 to $-10 \mu \mathrm{mol} \mathrm{kg}^{-1}$ according to McNeil et al. (2007). If we consider the latter work more reliable for waters south of $60^{\circ} \mathrm{S}$, the $\Delta \mathrm{C}_{T}^{\mathrm{dis}} \mathrm{SAB} 99$ are reasonable in deep waters and $\mathrm{C}_{\mathrm{ANT}}$ values as well.

Nevertheless, we have to question whether it is sensible to compare surface winter air-sea $\mathrm{C}_{T}$ disequilibrium values from the whole Indian Ocean for water masses formed in distinct regions of the Southwest Atlantic (AAIW), the Southeast Indian (SAMW) oceans, or the Weddell Sea (WSDW). The data of McNeil et al. (2007) show a large variability in waters denser than $\sigma_{\theta}=26.5$ (found south of $55^{\circ} \mathrm{S}$ ) suggesting the difficulty in defining a $\Delta C_{T}^{\text {dis }}$ value for intermediate and deep waters along the CD139 section.

Disequilibrium values obtained from the SAB99 method seem to be flawed; in upper and intermediate waters they lead to a $\mathrm{C}_{\mathrm{ANT}}$ underestimate, while in deep and bottom waters cancel any $\mathrm{C}_{\mathrm{ANT}}$ accumulation. The other carbonbased methods without any a priori disequilibrium assumption, IPSL and TrOCA, predict 1.34 and 1.13 times higher $\mathrm{C}_{\mathrm{ANT}}$ specific inventories in surface, SAMW and AAIW waters; while TTD and OCCAM estimates are 1.29 and 1.18 times higher. 


\section{2 $\mathrm{C}_{\mathrm{ANT}}$ relation with $\mathrm{CFC}-12$ and $\mathrm{CCl}_{4}$}

Transient tracers such as $\mathrm{CFC}-12$ and $\mathrm{CCl}_{4}$ provide useful information on oceanic ventilation and transport times and therefore on the uptake and storage of $\mathrm{C}_{\mathrm{ANT}}$ in the ocean. The increase of $\mathrm{C}_{\mathrm{ANT}}$ in the atmosphere began earlier than for these transient tracers. The presence of a significant CFC12 or $\mathrm{CCl}_{4}$ concentration indicates that the water parcel was exposed to anthropogenic $\mathrm{CO}_{2}$ in the atmosphere. However, a region free of these tracers may still have significant amounts of $\mathrm{C}_{\mathrm{ANT}}$, leading to $\mathrm{C}_{\mathrm{ANT}}$ underestimation (e.g., Goyet and Brewer, 1993; Matsumoto and Gruber, 2005; Tanhua et al., 2004). Significant concentrations of $\mathrm{CCl}_{4}$ are detected in the atmosphere after 1940 compared to CFC-12, detected after 1960 , so $\mathrm{CCl}_{4}$ can be used to trace $\mathrm{C}_{\mathrm{ANT}}$ via the $\Delta C^{*}$ method (Holfort et al. 1998; Wallace, 2001).

Another important assumption that can cause significant biases in the $\Delta C^{*}$-based $C_{\mathrm{ANT}}$ estimations is that CFCs would provide accurate ventilation ages (Matsumoto and Gruber, 2005). This assumption is only true if several conditions are fulfilled: first that preformed tracers were saturated and second, that transport is mainly advective. Mixing biases on age are practically compensated when different but significant tracer concentration waters mix within a linear trend in the atmospheric time evolution (e.g., Haine and Hall, 2002). According to Matsumoto and Gruber (2005) using singletracer ages in the $\Delta C^{*}$ method only apply to CFC ages less than 30 years causing limited biases in the $\mathrm{C}_{\mathrm{ANT}}$ estimation as both tracers, $\mathrm{CFCs}$ and $\mathrm{C}_{\mathrm{ANT}}$, increase roughly linearly in the 1990s.

To assess which method provides a more robust $\mathrm{C}_{\mathrm{ANT}}$ estimate we can study the relationship between the partial pressures of $\mathrm{CFC}-12$ (pCFC-12), $\mathrm{CCl}_{4}\left(\mathrm{pCCl}_{4}\right)$ (calculated assuming $100 \%$ saturation and using solubility equations from Warner and Weiss (1985) and Bullister and Wisegarver (1998), respectively) and the theoretical upper and lower limits of oceanic $\mathrm{C}_{\mathrm{ANT}}$. Assuming a mainly advective transport, with low mixing, the theoretical time evolution of oceanic $\mathrm{C}_{\mathrm{ANT}}$ can be calculated for two different types of surface waters, with Antarctic (TA $=2280 \mu \mathrm{mol} \mathrm{kg}^{-1}, \theta=4^{\circ} \mathrm{C}$, $\mathrm{Sal}=34, \mathrm{PO}_{4}=2 \mu \mathrm{mol} \mathrm{kg}^{-1}$ and $\mathrm{SiO}_{2}=20 \mu \mathrm{mol} \mathrm{kg}^{-1}$, Revelle $=13)$ and subtropical $\left(\mathrm{TA}=2340 \mu \mathrm{mol} \mathrm{kg}^{-1}, \theta=17^{\circ} \mathrm{C}\right.$, $\mathrm{Sal}=35.5, \mathrm{PO}_{4}=0.2 \mu \mathrm{mol} \mathrm{kg}^{-1}$ and $\mathrm{SiO}_{2}=3 \mu \mathrm{mol} \mathrm{kg}^{-1}$, Revelle=10) origins, using the atmospheric evolution of $\mathrm{CO}_{2}$ in the southern hemisphere and a preindustrial $\mathrm{CO}_{2}$ value of 280 ppmv, and $\mathrm{CO}_{2}$ constants from Lueker et al. (2000). Physical and chemical characteristics for surface waters in the subtropical Indian Ocean and the Indian sector of the Southern Ocean were taken from the GLODAP atlas and Metzl et al. (2006), Revelle factors are in agreement with Sabine et al. (2004). The theoretical curves are only valid under time-constant temperature, salinity and alkalinity, an assumption that is compromised by global warming in the ocean (e.g., Levitus et al., 2001), the likely alkalinity changes due to ocean acidification (e.g., Sarma et al., 2002), and

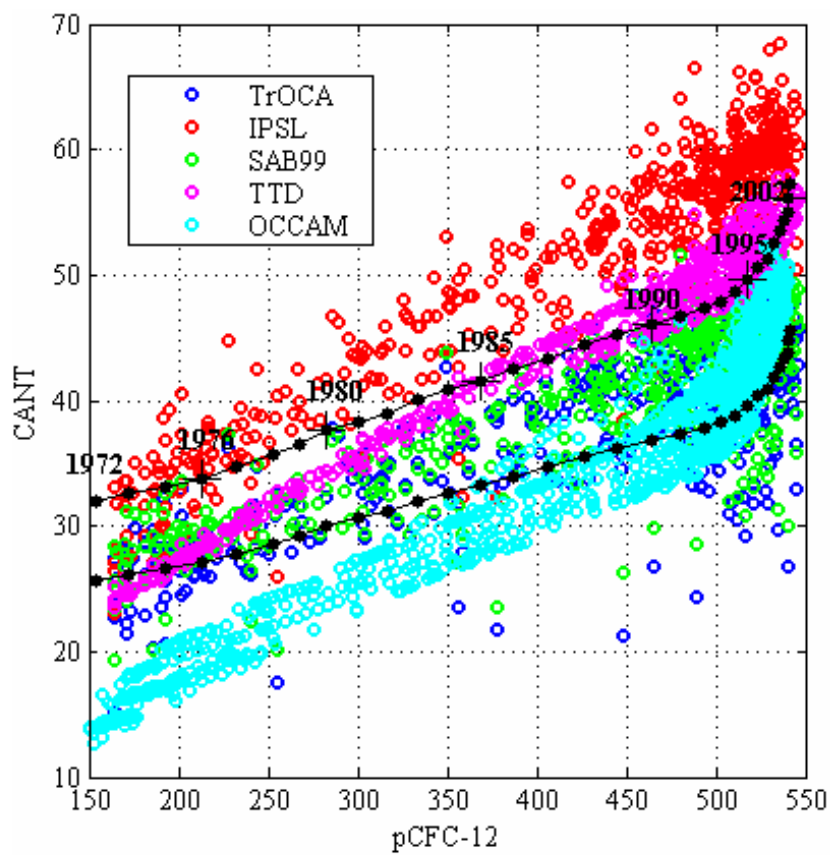

Fig. 10. Partial pressure of $\mathrm{CFC}-12$ (ppt) and $\mathrm{C}_{\mathrm{ANT}}$ estimates $\left(\mu \mathrm{mol} \mathrm{kg}{ }^{-1}\right)$ for upper waters with potential temperature higher than $5^{\circ} \mathrm{C}$, pressure higher than $200 \mathrm{dbar}$ and $\mathrm{CFC}-12$ age less than 30 years. Also shown in black is the atmospheric evolution of CFC12 and $\mathrm{C}_{\mathrm{ANT}}$ using Revelle factors of 10 and 13 (see text for details), some time markers are shown.

salinity increases (e.g., McDonagh et al. 2005). Mixing should be relevant in deep and bottom waters according to the formation mechanism of CDW and AABW. Consequently, the calculated curves should only be considered as indicative of the possible upper and lower $\mathrm{C}_{\mathrm{ANT}}$ evolution limits in the upper water of the subtropical Indian Ocean since both will be overestimations in deep and bottom waters, where mixing overcomes advection.

The relationship between pCFC-12 and $\mathrm{C}_{\mathrm{ANT}}$ in upper waters is shown in Fig. 10, along with the theoretical curves. IPSL stands out with high $\mathrm{C}_{\mathrm{ANT}}$ values compared with the upper $($ Revelle $=10)$ theoretical limit. Despite being based on different approaches the TrOCA and the SAB99 $\mathrm{C}_{\mathrm{ANT}}$ values are very similar in between the two theoretical limits. $\mathrm{C}_{\mathrm{ANT}}$ TTD values approach the upper limit towards the surface (where most waters have a subtropical origin) and the lower one towards the AAIW layer. OCCAM is the opposite of IPSL, with lower than any expected values. However, despite the fact that CFC-12 penetration in OCCAM compares well with our data, temperature and salinity data seem to be lower than expected, so consequently pCFC- 12 in OCCAM is underestimated and the OCCAM pCFC-12 vs. $\mathrm{C}_{\mathrm{ANT}}$ relationship shown in Figure 10 is misleading.

For deep waters below $5^{\circ} \mathrm{C}$, Fig. 11 shows the relationships of pCFC- 12 and $\mathrm{pCCl}_{4}$ vs. $\mathrm{C}_{\mathrm{ANT}}$. In the case of $\mathrm{CCl}_{4}$ only waters where $\theta<3^{\circ} \mathrm{C}$ are studied because this tracer 


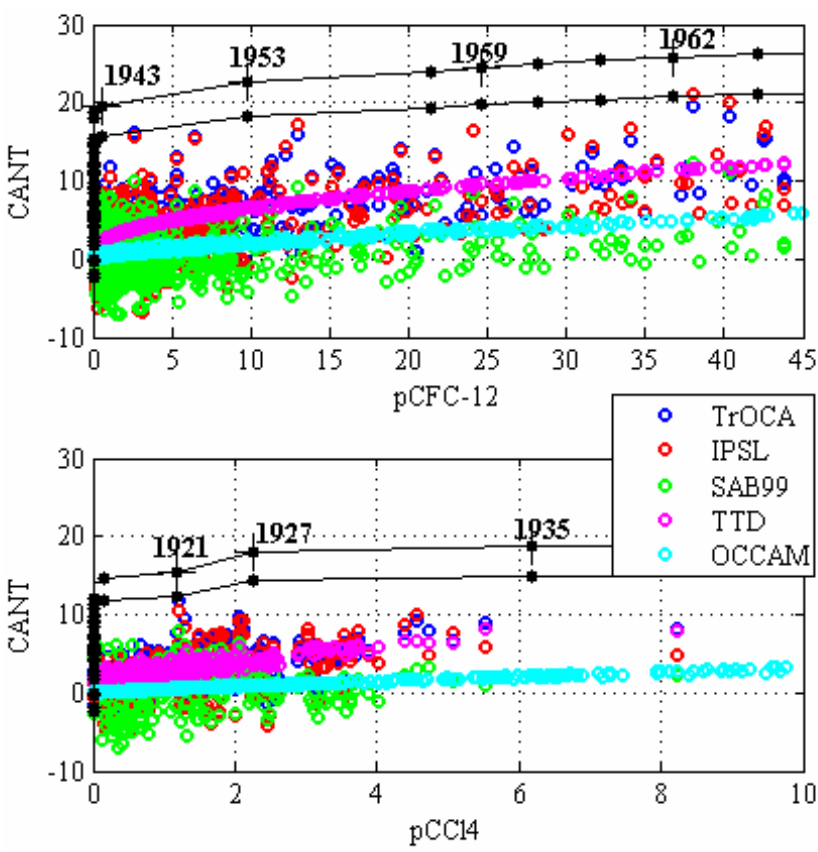

Fig. 11. (a) Partial pressure of CFC-12 (ppt) and (b) partial pressure of $\mathrm{CCl}_{4}$ (ppt) versus $\mathrm{C}_{\mathrm{ANT}} \mathrm{g}\left(\mu \mathrm{mol} \mathrm{kg}{ }^{-1}\right)$ estimates for deep waters with potential temperature lower than $5^{\circ} \mathrm{C}$, pressure higher than 200 dbar and CFC-12 age higher than 40 years. In the case of $\mathrm{CCl}_{4}$, the temperature limit is $3^{\circ} \mathrm{C}$. Also shown in black are the atmospheric evolution of $\mathrm{CFC}-12, \mathrm{CCl}_{4}$ and $\mathrm{C}_{\mathrm{ANT}}$ using Revelle factors of 10 and 13 (see text for details), some time markers are shown.

is decomposed at higher temperatures (Huhn et al. 2001). $\mathrm{C}_{\mathrm{ANT}}$ values in deep waters are generally lower than the theoretical value. This is not surprising as before 1960 the relationships between $\mathrm{CFC}-12$ or $\mathrm{CCl}_{4}$ and $\mathrm{C}_{\mathrm{ANT}}$ are very nonlinear, there is a strong mixing bias and some water masses incorporate ice-shelf waters formed with a $45 \%$ undersaturation in CFC-12 or $\mathrm{CCl}_{4}$ (Huhn et al., 2001). Significant tracer concentrations are found in deep Indian waters which points to a likely exposure to atmospheric $\mathrm{C}_{\mathrm{ANT}}$ levels of these waters when formed. Higher levels of pCFC- 12 and $\mathrm{pCCl}_{4}$ below $4000 \mathrm{dbar}$ were found on the western part of the section (Fig. 5) where younger AABW arrives to the section (Orsi et al., 1999). The SAB99 and OCCAM mean concentrations in Fig. $11 \mathrm{~b}$ are $0.4 \pm 2.8$ and $0.4 \pm 0.6 \mu \mathrm{mol} \mathrm{kg}^{-1}$, while respectively for IPSL, TrOCA and TTD methods it is $1.5 \pm 3,3 \pm 3$, and $3 \pm 2 \mu \mathrm{mol} \mathrm{kg}^{-1}$.

Neither Fig. 10 nor 11 show the lower part of the AAIW layer, but here TrOCA and TTD yield similar $\mathrm{C}_{\mathrm{ANT}}$ values, SAB99 is compromised by its discontinuity and IPSL estimates are $10 \mu \mathrm{mol} \mathrm{kg}^{-1}$ higher in the upper AAIW than in the lower AAIW.

\subsection{Evaluation of the five $\mathrm{C}_{\mathrm{ANT}}$ methods}

Taking into account i) that most of the water masses in the subtropical Indian Ocean have been formed in the Southern Ocean, a particularly challenging area for data- or modelbased $\mathrm{C}_{\mathrm{ANT}}$ estimates, and ii) the uncertainties inherent for the set of five $\mathrm{C}_{\mathrm{ANT}}$ methods here evaluated; we attempted to summarise the consistency of each method using the knowledge about water mass formation and the relation between $\mathrm{C}_{\mathrm{ANT}}$ estimates and transient-tracers in five water mass layers defined along the $32^{\circ} \mathrm{S}$ Indian Ocean section.

Upper surface waters, shallower than about 200 dbars, occupy a small fraction of the whole water column. Carbonbased methods are unable to properly correct for biological activity and therefore unable to estimate $\mathrm{C}_{\mathrm{ANT}}$ (Fig. 8, Table 1), while TTD is based on tracer distributions independent of biological activity, but affected by seasonality; and OCCAM assumes $\mathrm{CO}_{2}$ air-sea equilibration, which is not always true. Despite the uncertainties, we consider TTD and OCCAM more reliable in the surface layer, and therefore the inventory here would be $7 \pm 0.2 \mathrm{molC} \mathrm{m}^{-2}$.

At the SAMW layer, between roughly 200-700 dbars, carbon-based, TTD and OCCAM show relatively good agreement in $\mathrm{C}_{\mathrm{ANT}}$ values (to within $\pm 6 \mu \mathrm{mol} \mathrm{kg}^{-1}$ ) and inventories $\left( \pm 2 \mathrm{molC} \mathrm{m}^{-2}\right)$. CFC-12 levels are higher than $0.6 \mathrm{pmol} \mathrm{kg}^{-1}$ in this layer and the relation between surface $\mathrm{CO}_{2}$ and CFC saturation is one (Fig. 6 in Matear et al., 2003), so the TTD estimates offer highly reliable support to the other methods, except IPSL which appears too high. Thus the inventory in this layer would be $8.9 \pm 0.5 \mathrm{molC} \mathrm{m}^{-2}$ (mean from SAB99, TTD, TrOCA and OCCAM).

In the AAIW layer, $\approx 700-1500$ dbars, the situation is more complicated. CFC levels below $1000 \mathrm{dbars}$ sharply change to values lower than $0.5 \mathrm{pmol} \mathrm{kg}^{-1}$, and $\mathrm{CO}_{2} / \mathrm{CFC}$ saturation varies between $0.8-0.9$ in the formation area of AAIW, at the Brazil-Malvinas current confluence, consequently, the uncertainty in $\mathrm{C}_{\mathrm{ANT}}$ TTD increases. OCCAM, predicts a CFC- 12 penetration in agreement with observations, and $\mathrm{C}_{\mathrm{ANT}}$ values in agreement with the other methods, despite this, relatively low inventories are obtained because of the density field after the misleading temperature and salinity fields. $\mathrm{C}_{\text {ANT }}$ distributions obtained from TrOCA, TTD and OCCAM are quite similar (Figs. 6 and 7), while SAB99 has the discontinuity below $1200 \mathrm{dbar}$ and, IPSL estimates are $10 \mu \mathrm{mol} \mathrm{kg}^{-1}$ high in the upper AAIW (Fig. 5). No definitive support for any data method can be derived from the relation with tracers between 1000-1500 dbars where CFC-12 is too low and $\mathrm{CCl}_{4}$ is affected by decomposition. However, SAB99 can be disregarded because of the unreasonable discontinuity and OCCAM because of its inaccurately simulated density field. Thus an inventory of $9.4 \pm 0.1 \mathrm{molC} \mathrm{m}^{-2}$ can be assigned to the AAIW layer (mean from TTD and TrOCA).

The situation becomes more complicated in deep and bottom waters where $\mathrm{C}_{\mathrm{ANT}}$ estimates are mostly below 
$10 \mu \mathrm{mol} \mathrm{kg}^{-1}$, less than the detection limit for any method. Here OCCAM fails to predict any CFC-12 or $\mathrm{CCl}_{4}$ signal in these layers while data shows an increase with depth in their values, especially $\mathrm{CCl}_{4}$ below 3500 dbars. SAB99 $\mathrm{C}_{\mathrm{ANT}}$ estimates distribute randomly around zero at these layers. As a result, a low confidence is attributed to SAB99 or OCCAM in these layers. The TTD, TrOCA and IPSL methods predict significant and consistent $\mathrm{C}_{\mathrm{ANT}}$ values, from 0 to $10 \mu \mathrm{mol} \mathrm{kg}^{-1}$, except at the NADW core where they agree with $\mathrm{C}_{\mathrm{ANT}} \approx 0 \mu \mathrm{mol} \mathrm{kg}{ }^{-1}$. Relying on TTD, TrOCA and IPSL on both layers, the mean inventory would be $1.5 \pm 0.8$ and $1.3 \pm 0.1 \mathrm{molC} \mathrm{m}^{-2}$ in deep and bottom waters, respectively.

Summing up, we would suggest a best estimate for the water column specific inventory in the subtropical Indian Ocean of $28 \pm 2 \mathrm{molC} \mathrm{m}^{-2}$, which is significantly higher than the $\Delta \mathrm{C}^{*}$ value, $24 \pm 2 \mathrm{molC} \mathrm{m}^{-2}$.

\section{Conclusions}

This work investigates the $\mathrm{C}_{\mathrm{ANT}}$ penetration and inventory in the subtropical Indian Ocean along $32^{\circ} \mathrm{S}$ calculated with data collected in 2002. Five different methods are compared and discussed: three carbon-based methods ( $\triangle C^{*}$, IPSL and TrOCA), TTD and a simulation from the OCCAM global model. Comparatively, the $\Delta C^{*}$ method seems to yield too shallow penetration of $\mathrm{C}_{\mathrm{ANT}}$, with no or very low $\mathrm{C}_{\mathrm{ANT}}$ detected in deep or bottom waters, mainly due to the formulation and assumptions of $\Delta \mathrm{C}_{T}^{\mathrm{dis}}$. Our results indicate that SAB99 $\Delta \mathrm{C}_{T}^{\mathrm{dis}}$ values are inconsistent with the current airsea $\mathrm{CO}_{2}$ disequilibrium found in current Indian Ocean winter $\Delta \mathrm{C}_{T}^{\mathrm{dis}}$ values. Although this could also be misleading taking into account that water masses are usually formed in particular times and areas of the ocean.

Previous estimates of $\mathrm{C}_{\mathrm{ANT}}$ inventory in the subtropical Indian Ocean with the $\Delta C^{*}$ method appear to be underestimates. Considering the $\mathrm{C}_{\mathrm{ANT}}$ estimates derived from those methods consistent with the tracer distributions and the knowledge about water masses, our best estimate for the mean $\mathrm{C}_{\mathrm{ANT}}$ specific inventory is $28 \pm 2 \mathrm{molC} \mathrm{m}^{-2}$ which compares with $24 \pm 2 \mathrm{molC} \mathrm{m}^{-2}$ from $\Delta \mathrm{C}^{*}, 17 \%$ higher.

These conclusions, so far, apply only to the Indian Ocean subtropical gyre. Despite this, our conclusions may have important implications not only for quantifying the uptake and storage of $\mathrm{C}_{\mathrm{ANT}}$ in the Indian Ocean basin, but also for predicting the consequences of acidification on the local carbon cycle and marine biota. Although tedious, comparison exercises within other ocean basins are still necessary and revealing. Combining them with time-evolution approaches from repeat sections or time-series analysis will further help to constrain how, where and how much $\mathrm{C}_{\mathrm{ANT}}$ is penetrating into the ocean and also the data and model-based $\mathrm{C}_{\mathrm{ANT}}$ estimation methods.

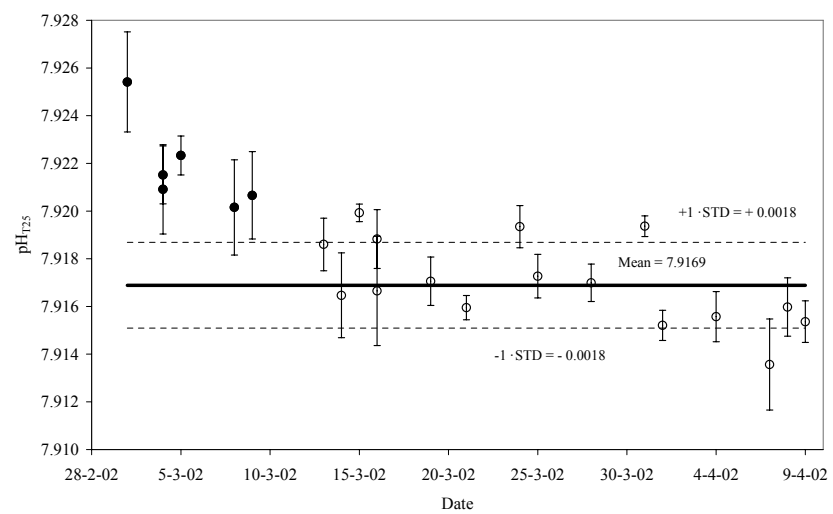

Fig. A1. Spectrophotometric pH25T measurements on the CRM batch 55 during the cruise. Each set of analyses consists of 7 to 8 measurements from the same CRM bottle. The first six sets of $\mathrm{CRM} \mathrm{pH}$ analysis (black dots) were discarded in the calculation of the final mean and standard deviation (STD), 7.9169 \pm 0.0018 . Note that the $\mathrm{pH}$ values contain the $\mathrm{R}$ and 0.0047 corrections.

\section{Appendix A}

\section{Further information on the $\mathrm{CO}_{2}$ data quality assessment}

\section{A1 Quality assessment on the $\mathrm{pH}$ measurements}

Method details: $\mathrm{pH}$ was measured spectrophotometrically following Clayton and Byrne (1993) using a seawater mcresol purple dye solution. Samples were analyzed in optical cells with a $10-\mathrm{cm}$ path length thermostated at $25 \pm 0.2^{\circ} \mathrm{C}$ in a CECIL 3041 spectrophotometer. Following determination of the blank, absorbance measurements were done. $\mathrm{pH}$ values are reported on the total scale at $25^{\circ} \mathrm{C}\left(\mathrm{pH}_{T 25}, \mathrm{~mol} \mathrm{~kg}_{\text {- }} \mathrm{sw}^{-1}\right)$.

Accuracy: practically every other day during the CD139 cruise (24 over 45 days), seven to eight samples from a CRM bottle (batch 55, certified chemical characteristics for salinity, 33.506; silicate, $2.7 \mu \mathrm{mol} \mathrm{kg}^{-1}$; nitrate, $0.46 \mu \mathrm{mol} \mathrm{kg}^{-1}$; nitrite, $0.0 \mu \mathrm{mol} \mathrm{kg}-1$; phosphate, $0.41 \mu \mathrm{mol} \mathrm{kg}{ }^{-1}$; total alkalinity, $2227.85 \pm 0.54 \mu \mathrm{mol} \mathrm{kg}^{-1}$; and total inorganic carbon, $2012.06 \pm 0.34 \mu \mathrm{mol} \mathrm{kg}^{-1}$ ) were drawn carefully to avoid bubbles and analysed for $\mathrm{pH}$ using the spectrophotometric method. Those chemical characteristics combined with the dissociations constants from Lueker et al. (2000) and an Excel-based $\mathrm{CO}_{2}$ software program developed by M. Álvarez and F. F. Pérez, yield a theoretical $\mathrm{pH}_{T 25}$ value of 7.917. The mean and standard deviation of the seven or eight samples for each day is shown in Fig. A1. The first six sets of CRM pH analysis were too high compared to the theoretical value. There is no clear explanation for this; perhaps the transfer procedure from the CRM bottle into the $10 \mathrm{~cm}$ cell was not optimized at the beginning. Taking into account 16 of the 24 sets (white circles in Fig. A1) the mean value for the CRM measurements was 7.9169 \pm 0.0018 . This value takes into account the double addition correction (see below) 


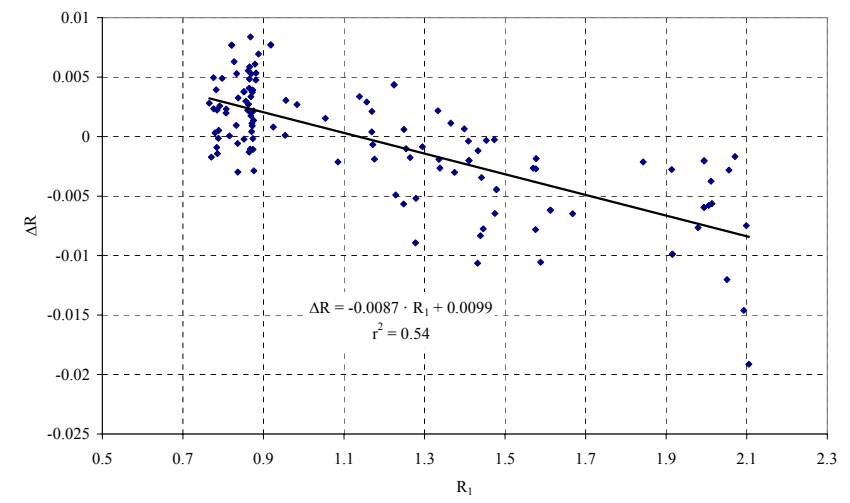

Fig. A2. Perturbation of sample $\mathrm{pH}$ induced by addition of indicator, expressed as $\Delta R\left(=R_{2}-R_{1}\right)$ as a function of $R_{1} . R_{1}$ is the first addition and $R_{2}$ the double addition. $R$ is the ratio between absorbances $((578 \mathrm{~A}-730 \mathrm{~A}) /(434 \mathrm{~A}-730 \mathrm{~A}))$.

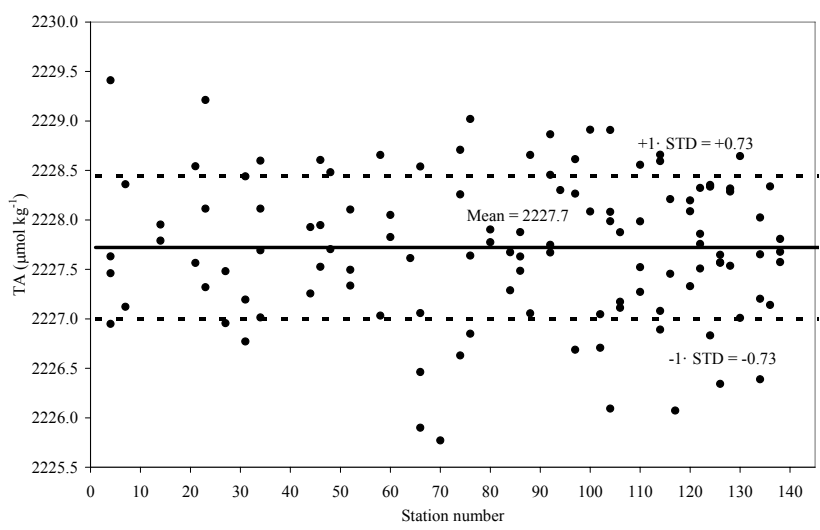

Fig. A3. Alkalinity $\left(\mu \mathrm{mol} \mathrm{kg}{ }^{-1}\right)$ measurements on the CRM batch 55 during the cruise against station number. The final mean and standard deviation (STD) for the 117 determinations was $2227.72 \pm 0.72 \mu \mathrm{mol} \mathrm{kg}^{-1}$.

and the 0.0047 addition proposed by DelValls and Dickson (1998) and Millero (2007).

Reproducibility: several cells from the same Niskin bottle were collected along the cruise to check the reproducibility of our measurements. Table A1 shows the characteristics of these deep water samples and the mean, standard deviation (STD) and number of cells collected from each bottle. The mean of the STD is 0.0009 which could be considered as the reproducibility of $\mathrm{pH}$ measurements during the cruise.

Dye addition correction: the injection of the indicator solution into seawater perturbs the sample $\mathrm{pH}$ slightly (Clayton and Byrne, 1993). The magnitude of this correction depends on the different acidity between the sample and the indicator solution. Consequently it should be quantified for each batch of dye solution. During the CD139 cruise, one batch of indicator solution done in seawater $(1 \mathrm{mM})$ was used, $100 \mu \mathrm{l}$ of this solution were added to the sample and the absorbance ratio $R_{1}=(578 \mathrm{~A}-730 \mathrm{~A}) /(434 \mathrm{~A}-730 \mathrm{~A})$ is calculated. From

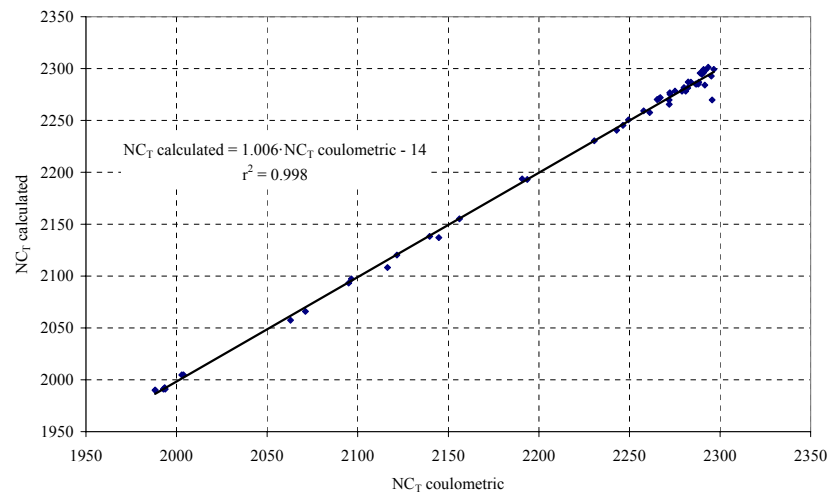

Fig. A4. Relationship between measured and calculated (from $\mathrm{pH}$ and alkalinity) salinity normalized total inorganic carbon $\left(\mathrm{NC}_{T}\right.$ in $\mu \mathrm{mol} \mathrm{kg}-1$ ).

a second addition of the dye solution another $R_{2}$ is also calculated. This operation is done over a wide $\mathrm{pH}$ range using the upper and deep CD139 samples. Figure A2 shows the relationship between $\Delta R\left(=R_{2}-R_{1}\right)$ and $R_{1}$. The correction equation is the following:

$\Delta R=-0.0087 \pm 0.0007 \times R_{1}+0.0099 \pm 0.0009$,

$r^{2}=0.54, n=123$

Consequently, the final $R\left(R_{\mathrm{ok}}\right)$ value is calculated as:

$R_{\mathrm{ok}}=R_{1}-\Delta R$

where $\Delta R$ is calculated with Eq. A1 as a function of $R_{1}$.

\section{A2 Quality assessment on the TA measurements}

TA was measured using automatic potentiometric titration with $0.1 \mathrm{M} \mathrm{HCl}$ to a final $\mathrm{pH}$ of 4.4 , with a Metrohm 6.0233.100 combination glass electrode and a Pt-100 probe to check the temperature (Pérez and Fraga, 1987). The electrode was standardised using a 4.4 buffer made in $\mathrm{CO}_{2}$ free seawater (Pérez et al., 2000). Concentrations are given in $\mu \mathrm{mol} \mathrm{kg-sw}^{-1}$.

The $0.1 \mathrm{~N}$ hydrochloric acid was prepared mixing $0.5 \mathrm{~mol}$ $(18.231 \mathrm{~g})$ of commercially $\mathrm{HCl}$ supplied by Riedel-deHaën (Fixanal 38285) with Milli-Q water into a graduated 5L beaker at controlled temperature conditions and referred to $20^{\circ} \mathrm{C}$ (Table A2). The variation caused by salinity after the titration is lower than 0.1 units, which is taken into account in the final TA calculation.

CRM analyses were performed in order to control the accuracy of our TA measurements (Fig. A3). Accordingly, the final $\mathrm{pH}$ of every batch of analyses was corrected to obtain the closest mean TA on the CRM analyses to the certified value. Table $\mathrm{A} 2$ shows the $\mathrm{pH}(\Delta \mathrm{pH})$ correction applied to each batch and the mean value of the CRM determinations after applying the former correction. 
Table A1. Location and physical characteristics of the samples analyzed for $\mathrm{pH}$ replicates. The mean, standard deviation (STD) $\mathrm{pH}_{25 T}$ and number of samples drawn from each bottle is shown. Note that the $\mathrm{pH}$ values contain the $\Delta R$ and 0.0047 corrections.

\begin{tabular}{cccccccccc}
\hline Lon & Lat & Station & Bottle & Prs (dbar) & Salinity & $\theta\left({ }^{\circ} \mathrm{C}\right)$ & Mean & STD & $n$ \\
\hline 35.01 & -32.90 & 36 & 6 & 783 & 34.7771 & 9.663 & 7.7894 & 0.0015 & 5 \\
36.52 & -33.02 & 41 & 3 & 4110 & 34.7359 & 0.778 & 7.6470 & 0.0005 & 5 \\
36.68 & -33.00 & 42 & 1 & 4824 & 34.6941 & 0.195 & 7.6260 & 0.0008 & 8 \\
56.26 & -33.99 & 70 & 2 & 2507 & 34.7172 & 1.983 & 7.6361 & 0.0005 & 4 \\
69.00 & -34.00 & 87 & 1 & 4595 & 34.6954 & 0.381 & 7.6211 & 0.0013 & 6 \\
78.50 & -30.75 & 98 & 2 & 3449 & 34.7323 & 1.190 & 7.6531 & 0.0011 & 7 \\
\hline
\end{tabular}

Table A2. Alkalinity analysis supplementary information for each batch of analysis: $\mathrm{N}_{\mathrm{HCl}}$ is the normality referred to $20^{\circ} \mathrm{C}$ of the hydrochloric solution used; $\triangle \mathrm{pH}$ is the $\mathrm{pH}$ correction applied to refer the TA determinations on the CRM to the corresponding nominal value (batch 55 with a certified TA of $2227.85 \pm 0.54 \mu \mathrm{mol} \mathrm{kg}-1$ ). The mean value of the TA measurements on the CRM samples is also shown (Fitted TA \pm standard deviation (number of analysis)). The average of the difference (Av. Dif. and number of duplicates) in the duplicate's analyses is shown.

\begin{tabular}{|c|c|c|c|c|c|c|}
\hline Batch & Day 2002 & Stations & $\mathrm{N}_{\mathrm{HCl}}$ & $\Delta \mathrm{pH}$ & Fitted TA & Av. Dif. \\
\hline 1 & 2 Mar & $1-2$ & 0.100145 & 0.0326 & $2227.9 \pm 0.3(2)$ & $0.9(46)$ \\
\hline 2 & 3-4 Mar & $4-5-7-11-12-13$ & 0.100145 & 0.013 & $2227.9 \pm 0.9(6)$ & $0.9(180)$ \\
\hline 3 & 5-6 Mar & $14-17-19-21$ & 0.100145 & 0.011 & $2227.8 \pm 0.4(4)$ & $1.0(110)$ \\
\hline 4 & 6-7 Mar & $23-25-27-29$ & 0.100145 & 0.022 & $2227.8 \pm 0.9(5)$ & $0.9(186)$ \\
\hline 5 & 8 Mar & $31-32$ & 0.100145 & 0.0292 & $2227.8 \pm 1.1(4)$ & $1.0(94)$ \\
\hline 6 & 9-10 Mar & $34-36-38-41$ & 0.100145 & 0.023 & $2227.9 \pm 0.7$ (4) & $1.1(162)$ \\
\hline 7 & 11-12 Mar & $43-44-46$ & 0.100109 & 0.0195 & $2227.9 \pm 0.5(5)$ & $1.1(94)$ \\
\hline 8 & 13-14 Mar & $48-50-52-54$ & 0.100109 & 0.028 & $2227.8 \pm 0.5$ & $1.1(162)$ \\
\hline 9 & $15 \mathrm{Mar}$ & $56-58$ & 0.100109 & 0.007 & $2227.9 \pm 1.2(2)$ & $1.2(94)$ \\
\hline 10 & 16-17 Mar & $60-62-64$ & 0.100109 & 0.019 & $2227.8 \pm 0.2$ & $1.2(144)$ \\
\hline 11 & $18 \mathrm{Mar}$ & $66-68$ & 0.100109 & 0.01 & $2227.8 \pm 1.1(4)$ & $1.3(96)$ \\
\hline 12 & $19 \mathrm{Mar}$ & $70-72$ & 0.100109 & 0.0072 & $2227.9 \pm 2.9(2)$ & $1.1(94)$ \\
\hline 13 & $20 \mathrm{Mar}$ & 74 & 0.100109 & 0.015 & $2227.9 \pm 1.1$ & $1.1(48)$ \\
\hline 14 & $21 \mathrm{Mar}$ & $76-78$ & 0.100109 & 0.0095 & $2227.8 \pm 1.1$ & $1.2(94)$ \\
\hline 15 & $22 \mathrm{Mar}$ & $80-82$ & 0.100179 & 0.0388 & $2227.8 \pm 0.1(2)$ & $1.5(96)$ \\
\hline 16 & 23-24 Mar & $84-86$ & 0.100179 & 0.0226 & $2227.8 \pm 0.7(6)$ & $1.2(97)$ \\
\hline 17 & $25 \mathrm{Mar}$ & $88-90$ & 0.100179 & 0.007 & $2227.9 \pm 1.1(2)$ & $1.1(96)$ \\
\hline 18 & 26-27 Mar & $92-94$ & 0.100179 & 0.02 & $2227.9 \pm 1.0(6)$ & $0.8(96)$ \\
\hline 19 & 29-30 Mar & $96-97-98$ & 0.100179 & 0.0258 & $2227.9 \pm 1.0$ & $1.0(142)$ \\
\hline 20 & $31 \mathrm{Mar}$ & $100-102$ & 0.100179 & 0.012 & $2227.7 \pm 1.0$ & $1.1(84)$ \\
\hline 21 & $2 \mathrm{Apr}$ & 104-106-108 & 0.100179 & 0.0173 & $2227.9 \pm 0.7(6)$ & $0.9(126)$ \\
\hline 22 & $3 \mathrm{Apr}$ & $110-112$ & 0.100179 & 0.0175 & $2227.8 \pm 0.6(4)$ & $1.0(86)$ \\
\hline 23 & $4 \mathrm{Apr}$ & 114 & 0.100099 & 0.013 & $2227.8 \pm 1.0(4)$ & $1.2(42)$ \\
\hline 24 & $5 \mathrm{Apr}$ & $116-117$ & 0.100099 & 0.0075 & $2226.5 \pm 1.3(5)$ & $1.0(84)$ \\
\hline 25 & $6 \mathrm{Apr}$ & 120 & 0.100099 & 0.0225 & $2227.9 \pm 0.5$ & $0.7(44)$ \\
\hline 26 & $7 \mathrm{Apr}$ & 122 & 0.100099 & 0.0093 & $2227.9 \pm 0.3(3)$ & $0.6(48)$ \\
\hline 27 & $8 \mathrm{Apr}$ & 124 & 0.100099 & 0.0315 & $2227.8 \pm 0.9(3)$ & $0.6(48)$ \\
\hline 28 & 9-10 Apr & $126-128$ & 0.100099 & 0.037 & $2227.8 \pm 0.8(8)$ & $0.8(88)$ \\
\hline 29 & $11 \mathrm{Apr}$ & $130-132$ & 0.100099 & 0.031 & $2227.8 \pm 1.2(3)$ & $1.2(88)$ \\
\hline 30 & $12 \mathrm{Apr}$ & 134 & 0.100099 & 0.036 & $2227.3 \pm 0.7$ (4) & $1.1(38)$ \\
\hline 31 & $12 \mathrm{Apr}$ & 136 & 0.100099 & 0.07 & $2227.7 \pm 0.9(2)$ & $1.0(46)$ \\
\hline 32 & $13 \mathrm{Apr}$ & 138 & 0.100099 & 0.024 & $2227.7 \pm 0.1(3)$ & $0.9(46)$ \\
\hline 33 & $14 \mathrm{Apr}$ & $140-142-144-145-146$ & 0.100099 & 0.031 & $2227.65 \pm 1(7)$ & $0.8(106)$ \\
\hline
\end{tabular}




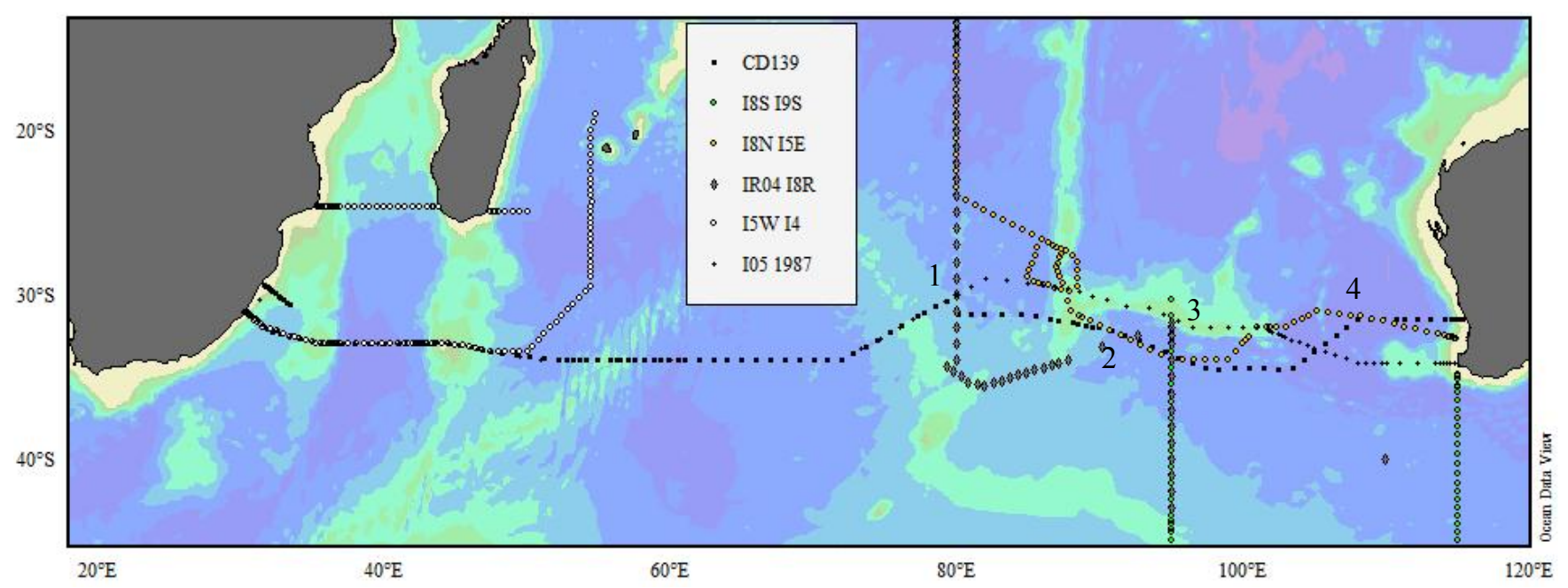

Fig. A5. Indian Ocean map showing the intersections or crossovers between the CD139 and GLODAP cruises. Each crossover is identified with a number.

Table A3. NADW characteristics $\left(1.8 \leq \theta \leq 2.3^{\circ} \mathrm{C}\right.$ and salinity $\geq 34.81$ ) from the $1995 \mathrm{I} 5 \mathrm{~W}$ and $2002 \mathrm{CD} 139$ cruises. Mean plus/minus standard deviation and number of samples (n) considered for the physical and chemical variables.

\begin{tabular}{lcc}
\hline Variable & $1995 \mathrm{I} 5 \mathrm{~W}(n=23)$ & $2002 \mathrm{CD} 139(n=30)$ \\
\hline Salinity & $34.815 \pm 0.003$ & $34.813 \pm 0.002$ \\
$\theta\left({ }^{\circ} \mathrm{C}\right)$ & $2.06 \pm 0.09$ & $2.02 \pm 0.10$ \\
$\mathrm{NO}_{3}\left(\mu \mathrm{mol} \mathrm{kg}^{-1}\right)$ & $26.7 \pm 0.1$ & $27.03 \pm 0.5$ \\
$\mathrm{PO}_{4}\left(\mu \mathrm{mol} \mathrm{kg}^{-1}\right)$ & $1.83 \pm 0.02$ & $1.85 \pm 0.02$ \\
$\mathrm{SiO}_{2}\left(\mu \mathrm{mol} \mathrm{kg}^{-1}\right)$ & $66.5 \pm 2.2$ & $70.4 \pm 2.2$ \\
$\mathrm{O}_{2}\left(\mu \mathrm{mol} \mathrm{kg}^{-1}\right)$ & $216.8 \pm 1.6$ & $215.9 \pm 1.9$ \\
$\mathrm{TA}\left(\mu \mathrm{mol} \mathrm{kg}^{-1}\right)$ & $2348 \pm 5(n=9)$ & $2346 \pm 2$ \\
$\mathrm{C}_{T}\left(\mu \mathrm{mol} \mathrm{kg}^{-1}\right)$ & $2219 \pm 2(n=9)$ & $2222 \pm 2$ \\
$\mathrm{CFC} 12\left(\mathrm{pmol} \mathrm{kg}^{-1}\right)$ & $0.00 \pm 0.00(n=9)$ & $0.00 \pm 0.00(n=18)$ \\
\hline
\end{tabular}

Usually, each sample was analyzed twice for alkalinity. Table A2 shows the average difference of the replicates analyzed during each batch of analysis. This difference was about $1.0 \mu \mathrm{mol} \mathrm{kg}-1$.

Surface seawater was used as "quasi-steady" seawater substandard, it consists in surface seawater taken from the nontoxic supply and stored in the dark into a large container (251) during 2 days before use. This substandard seawater was analyzed at the beginning and at the end of each batch of analyses to control the drift in the analyses for each batch.

\section{A3 Comparison between calculated and measured $C_{T}$}

As explained in the Data set section, salinity-normalized $\mathrm{C}_{T}$ calculated from $\mathrm{pH}_{T 25}$ and $\mathrm{TA}\left(\mathrm{NC}_{T}\right.$ calc) using Lueker et al. (2000) constants compared to normalized coulometric $\mathrm{C}_{T}\left(\mathrm{NC}_{T}\right.$ coul $)$ with a linear relationship:
$\mathrm{NC}_{T}$ calc $=1.006 \pm 0.007 \times \mathrm{NC}_{T}$ coul $-14 \pm 15 \quad\left(r^{2}=0.998\right.$, $n=51,0 \pm 4 \mu \mathrm{mol} \mathrm{kg}^{-1}$, mean \pm STD of the residuals). Figure A4 shows this relationship.

\section{A4 Crossover analysis for $\mathrm{CO}_{2}$ variables}

Another approach to evaluate the quality of physical or chemical data from a particular cruise is to compare the distribution of the tracers with already calibrated cruises at crossing or overlapping positions, at density or pressure levels where no temporal changes are expected. The final aim is to integrate the new cruise within the merge-calibrated data set. The Global Ocean Data Analysis Project (GLODAP, http://cdiac.esd.ornl.gov/oceans/glodap/Glodap_home. htm) (e.g., Key et al., 2004) was a major effort of the oceanographic community to produce calibrated and uniform data bases for the different ocean basins. Here, we use the GLODAP calibrated cruises for the Indian Ocean crossing the CD139 cruise (Fig. A5).

The CD139 western section from Africa to the Madagascar basin completely overlaps with the 1995 I5W section (Donohue and Toole, 2003) (Fig. A5). North Atlantic Deep Water (NADW) is confined by the Madagascar and Daves ridges to the Natal Valley and Mozambique basin (Toole and Warren, 1993). This water mass is the oldest in the Indian Ocean were no temporal trends in tracers should be found if we assume that hydrography and biogeochemical processes have been in steady state for the period covered by the data (1995-2002). NADW is characterized by a salinity maximum around $\theta=2^{\circ} \mathrm{C}$ and nitrate and $\mathrm{C}_{T}$ minimum.

We selected the tracer data between $1.8 \leq \theta \leq 2.3^{\circ} \mathrm{C}$ and salinity $\geq 34.81$ and studied the differences between the 1995 and 2002 cruises (Table A3). Silicate values in 2002 seem to be higher in $4 \mu \mathrm{mol} \mathrm{kg}^{-1}$, the TA difference is below 
Table A4. Mean and standard deviation (STD) difference between a GLODAP cruise and the 2002 CD139 CFC, $\mathrm{C}_{T}$ and TA data for each crossover (Xover number in Fig. A5). Samples are taken below 1500 dbar. The minimum number of stations for each cruise in each crossover is three. Except for the I5 cruise in 1987, the others were done in 1995.

\begin{tabular}{clrrrrrrrrr}
\hline Xover & Cruise & \multicolumn{2}{c}{ CFC-11 pmol kg } & \multicolumn{2}{c}{ CFC-12 $\mathrm{pmol} \mathrm{kg}^{-1}$} & \multicolumn{2}{c}{$\mathrm{C}_{T} \mu \mathrm{mol} \mathrm{kg}$} \\
\hline & & Mean & STD & Mean & STD & Mean & STD & Mean & STD \\
1 & IR04-I8R & 0.0021 & 0.0030 & 0.0037 & 0.0027 & -5.53 & 3.90 & 0.64 & 4.90 \\
1 & I5 & -0.0071 & 0.0002 & -0.0071 & 0.0002 & & & & \\
2 & I8N-I5E & -0.0073 & 0.0021 & -0.0027 & 0.0025 & -4.97 & 1.68 & -2.44 & 0.44 \\
2 & IR04-I8R & -0.0026 & 0.0014 & -0.0002 & 0.0028 & -7.05 & 1.75 & 0.84 & 1.34 \\
3 & I8N-I5E & -0.0069 & 0.0003 & -0.0001 & 0.0016 & -6.26 & 1.64 & -6.00 & 1.21 \\
3 & IR04-I8R & -0.0012 & 0.0025 & -0.0004 & 0.0007 & -4.05 & 2.23 & 1.07 & 0.57 \\
3 & I8S-I9S & -0.0015 & 0.0013 & -0.004 & 0.0001 & -3.35 & 0.06 & -2.74 & 1.62 \\
4 & I8N-I5E & -0.0024 & 0.0011 & -0.0011 & 0.0016 & -3.55 & 3.38 & 4.02 & 4.31 \\
\hline
\end{tabular}
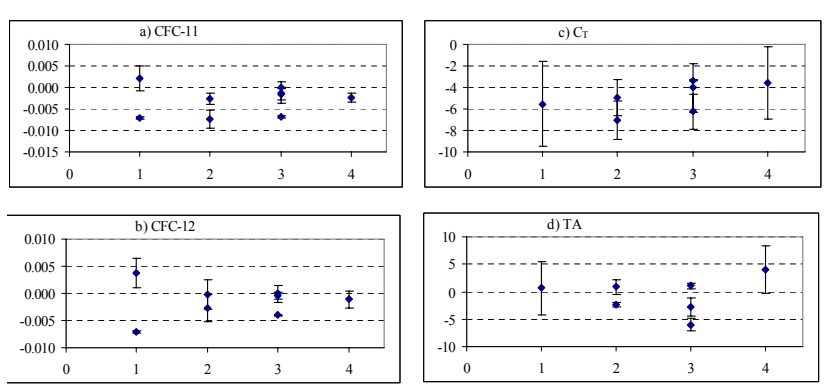

Fig. A6. Mean and standard deviation between the CD139 and GLODAP cruises at each crossover for (a) CFC-11; (b) CFC-12; (c) $\mathrm{C}_{T}$ and (d) TA. Each crossover is identified with a number as in Fig. A5. Results also shown in Table A4.

the threshold value used in the GLODAP comparison exercises $\left(6 \mu \mathrm{mol} \mathrm{kg}^{-1}\right.$, Lamb et al., 2002; Wanninkhof et al., 2003); in the case of $\mathrm{C}_{T}$, the 2002 data seem to be $4 \mu \mathrm{mol} \mathrm{kg}{ }^{-1}$ higher, but this value is still near the threshold value ( $4 \mu \mathrm{mol} \mathrm{kg} \mathrm{kg}^{-1}$, Lamb et al., 2002; Wanninkhof et al., 2003). No corrections are applied based in this first crossover.

The CD139 transindian section also intersects with other GLODAP lines in the Indian Ocean (Fig. A5). The quality and consistency of all the tracers measured on these cruises have been assessed in GLODAP and further information regarding the $\mathrm{CO}_{2}$ data can be found in SAB99. Here we present results for TA, $\mathrm{C}_{T}$, CFC-11 and CFC-12, the approximation used to calculate the differences between data sets follows the convention agreed for the synthesis effort on post WOCE cruises currently on course within the framework of the European CARBOOCEAN integrated project. The methodology is as follows: at least three stations from two cruises are selected falling within a limit of $100 \mathrm{~km}$, tracer data below $1500 \mathrm{~m}$ are selected and plotted against $\sigma_{4}$, a mean profile for each cruise is obtained at standard densities using a piecewise cubic hermite interpolation function, con- sequently a mean and standard deviation profile is obtained for each cruise, after subtracting those two profiles, a mean and standard deviation difference value is calculated for every pair of cruises at each crossover. Differences are considered significant when the mean value is higher than twice the standard deviation. The thresholds limits for correction are 0.005 for CFCs, $4 \mu \mathrm{mol} \mathrm{kg}^{-1}$ for $\mathrm{C}_{T}$ and $6 \mu \mathrm{mol} \mathrm{kg}^{-1}$ for TA.

Table A4 and Fig. A6 show the mean and standard deviation differences between any cruise and the CD139 one. At the light of these results CD139 CFCs and TA data are consistent with the other GLODAP cruises but CD139 $\mathrm{C}_{T}$ data seems to be higher in about 3 or $4 \mu \mathrm{mol} \mathrm{kg}^{-1}$. We decreased the calculated $\mathrm{CD} 139 \mathrm{C}_{T}$ data in $4 \mu \mathrm{mol} \mathrm{kg}^{-1}$.

\section{Appendix B}

\section{Water mass analysis}

The mixing of deep waters along the CD139 transindian section was resolved by means of an optimum multiparameter analysis (OMP) which consists on quantifying the proportions of source water types or end-members that contribute to a given water sample. The mixing is solved by minimizing the residuals of the linear mixing equations for $\theta, \mathrm{S}, \mathrm{O}_{2}$ and NO (with $R_{N}=9.3 \mathrm{~mol} \mathrm{O}_{2} \mathrm{~mol}^{-1}$, Laws, 1991; Anderson, 1995; Fraga et al., 1998) in a Non-Negative Least Squares sense, where mass is stringently conserved and the contributions of the different end-members must be positive. The selection of end-members and their physical and chemical characteristics here used were taken from Brea et al. (2004) and LoMonaco et al. (2005a). The end-members are the following: Antarctic Intermediate Water (AAIW), North Atlantic Deep Water (NADW), Indian Water (IW), Circumpolar Deep Water (CDW) and Weddell Sea Deep Water (WSDW). The contribution of ice-covered surface waters (ICSW) into WSDW is taken from Weppernig et al. (1996) as 
Table B1. Characteristics of the end-members used in the OMP mixing analysis. The correlation coefficient $\left(r^{2}\right)$ and the standard error (SE) of the predicted versus the measured parameters are also presented. Number of data 1266.

\begin{tabular}{lcccc}
\hline End-Member & $\theta\left({ }^{\circ} \mathrm{C}\right)$ & $\mathrm{S}$ & $\mathrm{SiO}_{2}\left(\mu \mathrm{mol} \mathrm{kg}^{-1}\right)$ & $\mathrm{NO}\left(\mu \mathrm{mol} \mathrm{kg}^{-1}\right)$ \\
\hline IW & 4 & 34.60 & 80 & 468 \\
AAIW & 3.14 & 34.14 & 18 & 548 \\
CDW & 1.60 & 34.72 & 120 & 496 \\
NADW & 2.02 & 34.905 & 31 & 447 \\
WSDW & -0.3 & 34.66 & 140 & 535 \\
$r^{2}$ & 0.9990 & 0.9921 & 0.9977 & 0.9281 \\
SE & 0.03 & 0.008 & 1.1 & 4 \\
\hline
\end{tabular}
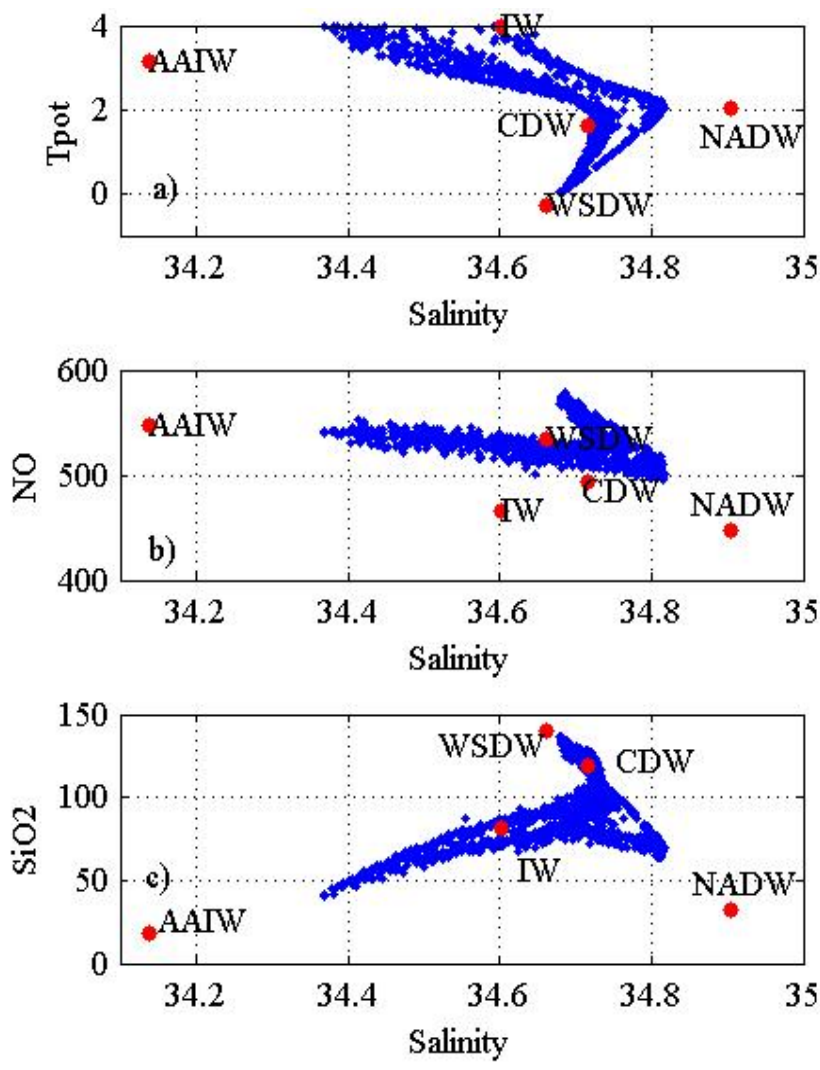

Fig. B1. (a) Potential temperature $\left({ }^{\circ} \mathrm{C}\right)$ - salinity, (b) NO $\left(\mu \mathrm{mol} \mathrm{kg}{ }^{-1}\right)$ - salinity, and (c) $\mathrm{SiO} 2\left(\mu \mathrm{mol} \mathrm{kg}^{-1}\right)$ - salinity diagrams for deep samples with $\theta<4{ }^{\circ} \mathrm{C}$ along the 2002 trans-Indian section $(n=1266)$.

$30 \%$. The $\theta-\mathrm{S}$ diagram and relation between $\mathrm{NO}-\mathrm{S}$ and $\mathrm{SiO}_{2}-$ $\mathrm{S}$ for $\theta<4^{\circ} \mathrm{C}$ waters and the end-members characteristics are showed in Fig. B1. As mixing figures for deep waters, IWAAIW-NADW-CDW, and for bottom waters, NADW-CDWWSDW. Mass is stringently conserved, a weight of 100 is given to its equation; $\theta, \mathrm{S}, \mathrm{SiO}_{2}$ and $\mathrm{NO}$ weights are 9, 8, 8 and 5 according to their relative error and variability.
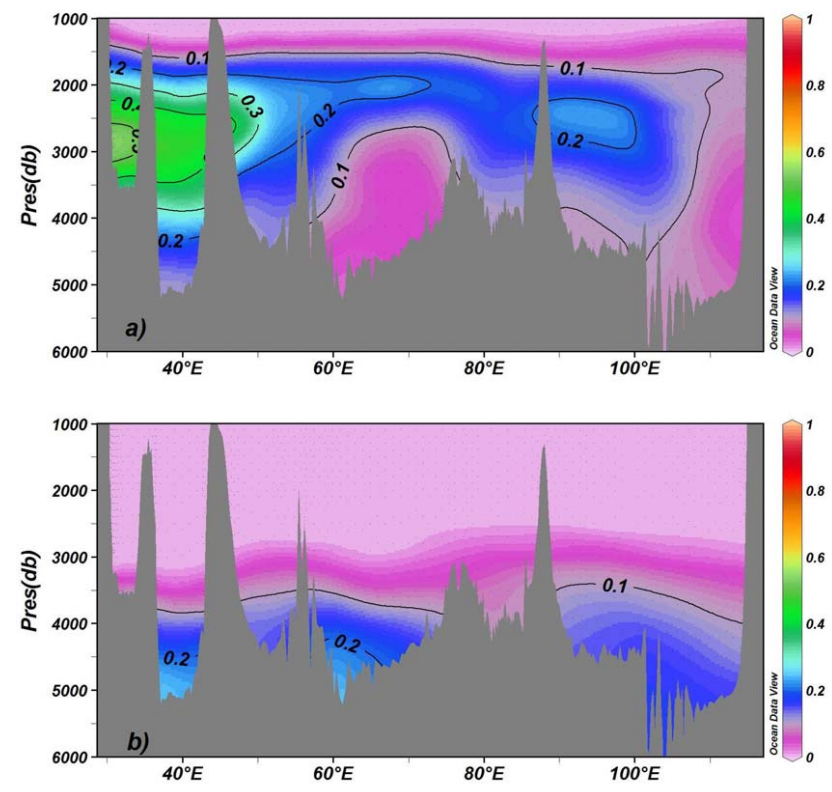

Fig. B2. Vertical distribution of (a) NADW, and (b) ICSW proportions along the trans-Indian CD139 section.

This OMP describes the physical and chemical variability of deep and bottom waters with a high degree of certainty. Note the high correlation between the measured and predicted variables used in the OMP and the low values of the mean residuals (Table B1).

Only the results for the water masses involved in the $\mathrm{C}_{\mathrm{ANT}}$ estimation following LoMonaco et al. (2005a), NADW and ICSW are shown (Fig. B2). The distribution of NADW is coherent with the deep water mass structure described by Donohue and Toole (2003), with higher contributions in the Natal Valley and Mozambique Basin, decreasing eastwards in favor of CDW and bottomwards in favor of WSDW. 
Acknowledgements. We thank the captain and crew who participated in the CD139 cruise and the scientists, particularly those responsible for the carbon, tracers, nutrient and oxygen analysis. B. McNeil kindly provided the empirical $\mathrm{CO}_{2}$ data. The fieldwork aboard RRS Charles Darwin along $32^{\circ} \mathrm{S}$ in the Indian Ocean in 2002 was supported principally by the UK Natural Environment Research Council under Grant NER/A/S/2000/00438 and under the Core Strategic Research Project Ocean Variability and Climate. The long-term OISO observational program is supported by three French Institutes, INSU (Institut National des Sciences de l'Univers), IPSL (Institut Pierre-Simon Laplace) and IPEV (Institut Paul-Emile Victor). This work is also part of the French program LEFE/Cyber/FlamenCO2 (SOLAS-France). A.Y. is funded on a UK National Environment Research Council (NERC) standard grant (NE/C00387X/1). Financial support was provided by grant ORCASEX (RYC-2006-001836), program Ramón y Cajal from the Spanish Ministry of Science and Technology.

Edited by: F. Joos

\section{References}

Álvarez, M., Ríos, A. F., Pérez, F. F., Rosón, G., and Bryden, H. L.: Transports and budgets of total inorganic carbon in the subpolar and temperate North Atlantic, Global Biogeochem. Cy., 17, 1002-1029, 2003.

Anderson, L. A.: On the hydrogen and oxygen content of marine phytoplankton, Deep Sea Res. I, 42, 1675-1680, 1995.

Anderson, L. G. and Sarmiento, J. L.: Redfield ratios of remineralization determined by nutrient data analysis, Global Biogeochem. Cy., 8, 65-80, 1994.

Bellerby R. G. J., Olsen, A., Furevik, T., and Anderson, L. A.: Response of the surface ocean $\mathrm{CO}_{2}$ system in the Nordic Seas and North Atlantic to climate change, in: Climate Variability in the Nordic Seas, edited by: Drange, H., Dokken, T. M., Furevik, T., Gerdes, R., and Berger, W., Geophys. Monogr. Ser., AGU, 189198, 2005

Benson, B. B. and Krause Jr., D.: The concentration and isotopic fractionation of oxygen dissolved in freshwater and seawater in equilibrium with the atmosphere, Limnol. Oceanogr., 29, 620632, 1984

Bopp, L., Monfray, P., Aumont, O., Dufresne, J.-L., Treut, H., Madec, G., Terray, L., and Orr, J.: Potential Impact of Climate Change on Marine Export Production, Global Biogeochem. Cy., 15, 81-99, 2001.

Brea, S., Álvarez-Salgado, X. A., Álvarez, M., Pérez, F. F., Mémery, L., Mercier, H., and Messias, M. J.: Nutrient mineralization rates and ratios in the eastern South Atlantic, J. Geophys. Res., 109, C05030, doi:10.1029/2003JC002051, 2004.

Brewer, P.G., Bradshaw, A. and Williams, R.: Measurements of total carbon dioxide and alkalinity in the North Atlantic Ocean in 1981. In: The Changing Carbon Cycle, A Global Analysis, edited by: Trabalka, J. and Reichle, D., Springer-Verlag, New York, USA, 358-381, 1986.

Brewer, P. G.: Direct observations of the oceanic $\mathrm{CO}_{2}$ increase, Geophys. Res. Lett. 5, 997-1000, 1978.

Broecker, W. S.: "NO" a conservative water mass tracer, Earth Planet. Sci. Lett. 23, 8761-8776, 1974.
Broecker, W. S., Takahashi, T., Simpson, H. J., and Peng, T. H.: Fate of fossil fuel carbon dioxide and the global carbon budget, Science, 206, 409-418, 1979.

Bryden, H. L., Cunningham, S., Benson, J., and co-authors: RRS Charles Darwin Cruise 139, 01 Mar-15 Apr 2002; Trans-Indian hydrographic section across $32^{\circ} \mathrm{S}$, Southampton Oceanography Centre Cruise Rep. 45, 122 pp., 2003.

Bullister, J. L. and Wisegarver, D.: The solubility of carbon tetrachloride in water and seawater, Deep-Sea Res. I, 45, 1285-1302, 1998.

Bullister, J. L. and Weiss, R. F.: Determination of CC13F and CC12F2 seawater and air, Deep-Sea Res., 25, 839-853, 1988.

Caldeira, K. and Duffy, P. B.: The role of the southern ocean in uptake and storage of anthroprogenic carbon, Science, 287, 620 622, 2000.

Chen, C.-T. A.: The oceanic anthropogenic $\mathrm{CO}_{2}$ sink, Chemosphere, 27, 1041-1064, 1993.

Chen, C. T. and Millero, F. J.: Gradual increase of oceanic carbon dioxide, Nature 277, 205-206, 1979.

Clayton, T. D. and Byrne, R. H.: Spectrophotometric seawater $\mathrm{pH}$ measurements: total hydrogen ion concentration scale concentration scale calibration of m-cresol purple and at-sea results, DeepSea Res. I, 40, 10, 2115-2129, 1993.

Coatanoan, C., Goyet, C., Gruber, N., Sabine, C. L. and Warner, M.: Comparison of two approaches to quantify anthropogenic carbon in the ocean: results from the northern Indian ocean, Global Biogeochem. Cy., 15, 11-25, 2001.

Cole, J. J., Prairie, Y. T., Caraco, N. F., McDowell, W. H., Tranvik, L. J., Striegl, R. G., Duarte, C. M., Kortelainen, P., Downing, J. A., Middleburg, J., and Melack, J.: Plumbing the global carbon cycle: Integrating inland waters into the terrestrial carbon budget, Ecosystems, 10, 171-184, 2007.

Conkright, M. E., Antonov, J. I., Baranova, O., Boyer, T. P., Garcia, H. E., Gelfeld, R., Johnson, D., Locarnini, R. A., Murphy, P. P., O'Brien, T. D., Smolyar, I., and Stephens, C.: NOAA Atlas NESDIS 42, WORLD OCEAN DATABASE 2001 Volume 1: Introduction, US Gov. Printing Office, Washington DC, USA, 160 pp., 2002.

DelValls, T. A. and Dickson, A. G.: The $\mathrm{pH}$ of buffers based on 2amino-2-hydroxymethyl-1,3-propanediol ("tris") in synthetic sea water, Deep-Sea Res. I, 45, 1541-1554, 1998.

Doney, S. C. and Bullister, J. L.: A chlorofluorocarbon section in the eastern North Atlantic, Deep Sea Res. I, 39, 1857-1883, 1992.

Donohue, K. and Toole, J.: A near-synoptic survey of the Southwest Indian Ocean, Deep-Sea Res., 50B, 1893-1931, 2003.

Duarte, C. M., Middelburg, J. J., and Caraco, N.: Major role of marine vegetation on the oceanic carbon cycle, Biogeosciences, $2,1-8,2005$, http://www.biogeosciences.net/2/1/2005/.

Dutay, J.-C., Bullister, J. L., Doney, S. C., et al.: Evaluation of ocean model ventilation with CFC-11: comparison of 13 global ocean models, Ocean Model., 4, 89-120, 2002.

Feely, R. A., Sabine, C. L., Takahashi, T., and Wanninkhof, R.: Uptake and storage of carbon dioxide in the oceans: The global $\mathrm{CO}_{2}$ survey, Oceanography, 14, 18-32, 2001.

Fine, R. A., Smethie, W. M., Bullister, Jr. J. L., Rhein, M., Min, D.-H., Warner, M. J., Poisson, A., and Weiss R. F.: Decadal ventilation and mixing of Indian Ocean waters, Deep-Sea Res. I, 55, 20-37, 2008. 
Fraga, F., Ríos, A. F., Pérez, F. F., and Figueiras, F. G.: Theoretical limits of oxygen:carbon and oxygen:nitrogen ratios during photosynthesis and the mineralization of the organic matter in the sea, Sci. Mar., 62, 161-168, 1998.

Goyet, C. and Brewer, P. G.: Biochemical properties of the oceanic carbon cycle, in: Modelling Oceanic Climate Interactions, edited by: Willebrand, J. and Anderson, D. L. T., NATO ASI Series, I 11, Springer, Berlin, Heidelberg, 271-297, 1993.

Goyet, C., Coatanoan, C., Eischeid, G., Amaoka, T., Okuda, K., Healy, R., and Tsunogai, S.: Spatial variation of total alkalinity in the northern Indian Ocean: a novel approach for the quantification of anthropogenic $\mathrm{CO}_{2}$ in seawater, J. Mar. Res. 57, 135-163, 1999.

Gruber, N., Sarmiento, J. L., and Stocker, T. F.: An improved method for detecting anthropogenic $\mathrm{CO}_{2}$ in the oceans, Global Biogeochem. Cy., 10, 809-837, 1996.

Gruber, N.: Anthropogenic $\mathrm{CO}_{2}$ in the Atlantic Ocean, Global Biogeochem. Cy., 12, 165-191, 1998.

Haine, T. W. N. and Hall, T. M.: A generalized transport theory: water mass composition and age, J. Phys. Oceanogr., 32, 19321946, 2002.

Hall T. M., and Primeau, F. W.: Separating the natural and anthropogenic air-sea flux of $\mathrm{CO}_{2}$ : The Indian Ocean, Geophys. Res. Lett., 31, L23302, doi:10.1029/2004GL020589, 2004.

Hall, T. M., Haine, T. W. N., and Waugh, D. W.: Inferring the concentration of anthropogenic carbon in the ocean from tracers, Global Biogeochem. Cy., 16(4), 1131, doi:10.1029/2001GB001835, 2002.

Hall, T. M., Waugh, D. W., Haine, T. W. N., Robbins, P. E., and Khaliwala, S.: Reduced estimates of anthropogenic carbon in the Indian ocean due to mixing and time-varying airsea $\mathrm{CO}_{2}$ disequilibrium, Global Biogeochem. Cy., 18, GB1031, doi:10.1029/2003GB002120, 2004.

Hanawa, K. and Talley, L. D. : Mode Waters, Ocean Circulation and Climate, G. Siedler and J. Church, editors, International Geophysics Series, Academic Press, 373-386, 2001.

Holfort, J., Johnson, K. M., Scheider, B., Siedler G., and Wallace, D. W. R.: Meridional transport of dissolved inorganic carbon in the South Atlantic Ocean, Global Biogeochem. Cy., 12, 479-99, 1998.

Hunh, O., Roether, W., Beining, P., and Rose, H.: Validity limits of carbon tetrachloride as an ocean tracer, Deep Sea Res. I, 48, 2025-2049, 2001.

IMBER report $\mathrm{N}^{\circ} 1$, Joint SOLAS/IMBER Ocean Carbon Research Implementation Plan (http://www.imber.info/products/Carbon_ Plan_final.pdf), 2006.

IPCC Report 2007 website: http://ipcc-wg1.ucar.edu/wg1/ wg1-report.html, 2007.

Jenkins, W.J.: ${ }^{3} \mathrm{H}$ and ${ }^{3} \mathrm{He}$ in the Beta triangle: observations of gyre ventilation and oxygen utilization rates, J. Phys. Oceangr., 17, 763-783, 1987.

Johnson, K. M., Wills, K. D., Butler, D. B., Johnson, W. K., and Wong, C. S.: Coulometric total carbon dioxide analysis for marine studies: maximizing the performance of an automated gas extraction system and coulometric detector, Mar. Chem. 44, 167188, 1993.

Karstensen, J. and Quadfasel, D.: Water subudcted into the Indian ocean subtropical gyre, Deep-Sea Res. II, 49, 1441-1457, 2002.

Keeling, C. D. and Whorf T. P.: Atmospheric $\mathrm{CO}_{2}$ records from sites in the SIO air sampling network. In Trends: A Compendium of Data on Global Change. Carbon Dioxide Information Analysis Center, Oak Ridge National Laboratory, US Department of Energy, Oak Ridge, Tennessee, USA, 2005.

Key, R. M., Kozyr, A., Sabine, C. L., Lee, K., Wanninkhof, R., Bullister, J.L., Feely, R. A., Millero, F. J., Mordy, C., and Peng, T.-H.: A global ocean carbon climatology: Results from Global Data Analysis Project (GLODAP), Global Biogeochem. Cy., 18, GB4031, doi:10.1029/2004GB002247, 2004.

Key, R. M., Kozyr, A., Sabine, C. L., Lee, K., Wanninkhof, R., Bullister, J., Feely, R. A., Millero, F., Mordy, C. and Peng, T.H.: A global ocean carbon climatology: Results from Global Data Analysis Project (GLODAP), Global Biogeochem. Cy., 18, GB4031, doi:10.1029/2004GB002247, 2004.

Kirkwood, D.S.: Nutrients: Practical notes on their determination in seawater. ICES Techniques in Marine Environmental Sciences report 17, International Council for the Exploration of the Seas, Copenhagen, Danmark, ISSN: 0903-2606, 25 pp., 1995.

Körtzinger, A., Mintrop, L., and Duinker, J. C.: On the penetration of anthropogenic $\mathrm{CO}_{2}$ into the North Atlantic Ocean, J. Geophys. Res., 103, 18681-18689, 1998.

Körtzinger, A., Hedges, J. I., and Quay, P. D.: Redfield ratios revisited: Removing the biasing effect of anthropogenic $\mathrm{CO}_{2}$, Limnol. Oceanogr., 46, 964-970, 2001.

Lamb, M. F., Sabine, C. L., Feely, R. A., Wanninkhof, R., Key, R. M., Johnson, G. C., Millero, F. J., Lee, K., Peng, T.-H., Kozyr, A., Bullister, J. L., Greeley, D., Byrne, R. H., Chipman, D. W., Dickson, A. G., Goyet, C., Guenther, P. R., Ishii, M., Johnson, K. M., Keeling, C. D., Ono, T., Shitashima, K., Tilbrook, B., Ono, T., Takahashi, R., Wallace, D. W. R., Watanabe, Y., Winn, C., and Wong, C. S.: Consistency and synthesis of Pacific Ocean $\mathrm{CO}_{2}$ survey data, Deep-Sea Res. II, 49, 21-58, 2002.

Large, W. and Yeager, S.: Diurnal to decadal global forcing for ocean and sea-ice models: the data sets and flux climatologies. CGD Division of the National Center for Atmospheric Research, NCAR Technical Note: NCAR/TN-460+STR, 66 pp., 2004.

Laws, E. A.: Photosynthetic quotients, new production and net community production in the open ocean, Deep Sea Res., 38, 143-167, 1991.

Levitus, S., Antonov, J. I., Wang, J., et al.: Anthropogenic warming of the earth's climate system, Science, 292, 267-270, 2001.

Lo Monaco, C., Metzl, N., Poisson, A., Brunet, C., and Schauer, B.: Anthropogenic $\mathrm{CO}_{2}$ in the Southern Ocean: Distribution and inventory at the Indian-Atlantic boundary (World Ocean Circulation Experiment line I6), J. Geophs. Res., 110, C06010, doi:10.1029/2004JC002643, 2005b.

Lo Monaco C., Goyet, C., Metzl, N., Poisson, A., and Touratier, F.: Distribution and inventory of anthropogenic $\mathrm{CO}_{2}$ in the Southern Ocean: comparison of three data-based methods, J. Geophs. Res., 110, C09S02, doi:10.1029/2004JC002571, 2005a.

Lueker, T. J., Dickson, A. G., and Keeling, C. D.: Ocean $p \mathrm{CO}_{2}$ calculated from dissolved inorganic carbon, alkalinity and equations for K1 and K2: validations based on laboratory measurements of $\mathrm{CO}_{2}$ in gas and seawater at equilibrium, Mar. Chem., 70, 105$119,2000$.

Hoppema, M., Roether, W., Bellerby, R. G. J., and De Baar, H. J. W.: Direct measurements reveal insignificant storage of anthropogenic $\mathrm{CO}_{2}$ in the abyssal Weddell Sea, Geophys. Res. Lett., 28, 1747-1750, 2001. 
Marsh, R., de Cuevas, B. A., Coward, A. C., Bryden, H. L., and Alvarez, M.: Thermohaline circulation at three key sections of the North Atlantic over 1985-2002, Geophys. Res. Lett. 32, L10604, doi:10.1029/2004GL022281, 2005.

Matear R. J., Wong, C. S., and Xie, L.: Can CFCs be used to determine anthropogenic $\mathrm{CO}_{2}$ ?, Global Biogeochem. Cy., 17, 1013, doi:10.1029/2001GB001415, 2003.

Matsumoto, K. and Gruber, N.: How accurate is the estimation of anthropogenic carbon in the ocean? An evaluation of the $\Delta C^{*}$ method, Global Biogeochem. Cy., 19, GB3014, doi:10.1029/2004GB002397, 2005

Matsumoto, K., Sarmiento, J. L., Key, J. M., et al.: Evaluation of ocean carbon cycle models with data-based metrics, Geophys. Res. Lett., 31, L07303, doi:10.1079/2003GL018970, 2004.

McCartney, M.: Subantartctic mode water, in: a voyage of discovery, Deep-Sea Res., 24 (Suppl.), 103-119, 1977.

McDonagh, E. L., Bryden, H. L., King, B. A., Sanders, R. J., Cunningham, S. A., and Marsh, R: Decadal changes in the south Indian ocean, J. Clim., 18, 1575-1590, 2005.

McDonagh, E. L., Bryden, H. L., King, B. A., Sanders, R. J.: The circulation of the Indian Ocean at $32^{\circ} \mathrm{S}$, Progr. Ocean., 79, 20 36, 2008.

McNeil B. I., Metzl, N., Key, R. M., Matear, R. J., and Corbiere, A.: An empirical estimate of the Southern Ocean air-sea $\mathrm{CO}_{2}$ flux, Global Biogeochem. Cy., 21, GB3011, doi:10.1029/2007GB002991, 2007.

McNeil, B. I., Tilbrook, B., and Matear, R. J.: Accumulation and uptake of anthropogenic $\mathrm{CO}_{2}$ in the Southern Ocean, south of Australia between 1968 and 1996, J. Geophys. Res., 106(C12), 31431-31445, 2001.

Mecking, S. and Warner, M. J.: Ventilation of Red Sea Water with respect to chlorofluorocarbons, J. Geophys. Res., 104, 1108711097, 1999.

Meredith, M. P., Watson, A. J., Van Scoy, K. A., and Haine, T. W. N.: Chlorofluorocarbon-derived formation rates of the deep and bottom waters of the Weddell Sea, J. Geophys. Res., 106, 28992919, 2001

Metzl, N., Brunet, C., Jabaud-Jan, A., Poisson, A., and Schauer, B.: Summer and winter air-sea $\mathrm{CO}_{2}$ fluxes in the Southern Ocean, Deep Sea Res. I, 53, 1548-1563, 2006.

Mikaloff Fletcher, S. E., Gruber, N., Jacobson, A. R., et al.: Inverse estimates of anthropogenic $\mathrm{CO}_{2}$ uptake, transport, and storage by the ocean, Global Biogeochem. Cy., 20, GB2002, doi:10.1029/2005GB002530, 2006.

Millero, F.: The marine inorganic carbon cycle, Chem. Rev., 107, 308-341, 2007.

Murata, A., Kumamoto, Y., Sasaki, K., Watanabe, S., Fukasawa, M.: Decadal increases of anthropogenic $\mathrm{CO}_{2}$ in the subtropical South Atlantic Ocean along $30^{\circ} \mathrm{S}$, J. Geophys. Res., 113, C06007, doi:10.1029/2007JC004424, 2008.

Orr, J. E., Fabry, V. J.; Aumont, O., Bopp, L., Doney, S. C., Feely, R. A. et al.: Anthropogenic ocean acidification over the twentyfirst century and its impact on calcifying organisms, Nature, 437, 681-686, 2005

Orr, J. E., Maier-Reimer, E., Mikolajewicz, U., Monfray P., Sarmiento, J. L., Toggweiler, J. R., Taylor, N. K., Palmer, J. Gruber, N., Sabine, C. L. LeQuéré, C., Key, R. M., and Boutin, J.: Estimates of anthropogenic carbon uptake from four threedimensional global ocean models, Global Biogeochem. Cy., 15,
43-60, 2001.

Orsi A. H., Smethie Jr., W. M., and Bullister, J. L.: On the total input of Antarctic waters to the deep ocean: A preliminary estimate from chlorofluorocarbon measurements, J. Geophys. Res., 107, 3122, doi:10.1029/2001JC000976, 2002.

Orsi A. H., Johnson, G. C., and Bullister, J. L.: Circulation, mixing and production of Antarctic Bottom Water, Progr. Oceanogr., 43, 55-109, 1999.

Oschlies, A.: Model-derived estimates of new production: New results point towards lower values. Deep-Sea Res. II, 48, 2173 2197, 2001.

Papaud A. and Poisson, A.: Distribution of dissolved $\mathrm{CO}_{2}$ in the Red Sea and correlation with other geochemical tracers, J. Mar. Res., 44, 385-402, 1986.

Pérez, F. F., Álvarez, M., and Ríos, A. F.: Improvements on the back-calculation technique for estimating anthropogenic $\mathrm{CO}_{2}$, Deep-Sea Res. I, 49, 859-875, 2002.

Pérez, F. F. and Fraga, F.: A precise and rapid analytical procedure for alkalinity determination, Mar. Chem., 21, 169-182, 1987.

Pérez, F. F., Ríos, A. F., Rellán, T., and Álvarez, M.: Improvements in a fast potentiometric seawater alkalinity determination, Ciencias Marinas, 26, 463-478, 2000.

Poisson, A. and Chen, C.-T. A.: Why is there little anthropogenic $\mathrm{CO}_{2}$ in the Antarctic Bottom Water?, Deep-Sea Res. Part A, 34, 1255-1275, 1987.

Prairie, Y. T. and Duarte, C. M.: Direct and indirect metabolic $\mathrm{CO}_{2}$ release by humanity, Biogeosciences, 4, 215-217, 2007, http://www.biogeosciences.net/4/215/2007/.

Sabine, C. L., Key, R. M., Johnson, K. M. , Millero, F. J., Poisson, A., Sarmiento, J. L., Wallace, D. W. R., and Winn, C. D. Anthropogenic $\mathrm{CO}_{2}$ inventory of the Indian Ocean, Global Biogeochem. Cy., 13, 179-198, 1999.

Sabine, C. and Feely, R. A.: Comparison of Recent Indian Ocean Anthropogenic $\mathrm{CO}_{2}$ Estimates With a Historical Approach, Global Biogeochem. Cy., 15, 31-42, 2001.

Sabine, C. L., Feely, R. A., Gruber, N., and co-authors: The oceanic sink for anthropogenic $\mathrm{CO}_{2}$, Science, 305, 367-371, 2004.

Sallée, J. B., Wienders, N., Morrow, R., and Speer, K.: Formation of subantarctic mode water in the southeastern Indian Ocean, Ocean Dyn., 56, 525-542, 2006.

Sandrini, S., Ait-Ameur, N., Rivaro, P., Massolo, S., Touratier, F., Tositti, L., and Goyet, C.: Anthropogenic carbon distribution in the Ross Sea, Antarctica, Antarc. Sci., 19, 395-407, 2007.

Sarma, V. V. S. S., Ono, T., and Saino, T.: Increase of total alkalinity due to shoaling of aragonite saturation horizon in the Pacific and Indian Oceans: Influence of anthropogenic carbon inputs, Geophys. Res. Lett., 29(20), 1971, doi:10.1029/2002GL015135, 2002.

Sloyan, B. M. and Rintoul, S. R.: Circulation, renewal, and modification of Antarctic mode and intermediate water, J. Phys. Oceanogr., 31, 1005-1030, 2001.

Takahashi, T., Sutherland, S. C., Sweeney, C., Poisson, A., Metzl, N., Tillbrook, B., Bates, N., Wanninkhof, R., Feely, R. A., Sabine, C., Olafsson, J., and Nojiri, Y.: Global sea-air $\mathrm{CO}_{2}$ flux based on climatological surface ocean $p \mathrm{CO}_{2}$, and seasonal biological and temperature effects, Deep-Sea Res. II, 49, 16011622, 2002.

Talley, L. D.: Antarctic Intermediate Water in the South Atlantic, The South Atlantic: Present and Past Circulation, edited by: 
Wefer, G., Berger, W. H., Siedler, G., and Webb, D., SpringerVerlag, 219-238, 1996.

Tanhua, T., Waugh, D. W., and Wallace, D. W. R.: Use of $\mathrm{SF}_{6}$ to Estimate Anthropogenic $\mathrm{CO}_{2}$ in the Upper Ocean, J. Geophys. Res., 113, C04037, doi:10.1029/2007JC004416.

Touratier, F. and Goyet, C.: Definition, properties, and Atlantic distribution of the new tracer TrOCA, J. Mar. Syst. 46, 169-179, 2004a.

Touratier, F. and Goyet, C.: Applying the new TrOCA approach to assess the distribution of anthropogenic $\mathrm{CO}_{2}$ in the Atlantic Ocean, J. Mar. Syst. 46, 181-197, 2004b.

Touratier, F., Azouzi, L., and Goyet, C.: CFC-11, $\Delta{ }^{14} \mathrm{C}$ and ${ }^{3} \mathrm{H}$ tracers as a means to assess anthropogenic $\mathrm{CO}_{2}$ concentrations in the ocean, Tellus, 59B, 318-325, 2007.

Vázquez-Rodríguez, M., Touratier, F., Lo Monaco, C., Waugh, D. W., Padin, X. A., Bellerby, R. G. J., Goyet, C., Metzl, N., Ros, A. F., and Pérez, F. F.: Anthropogenic carbon distributions in the Atlantic Ocean: data-based estimates from the Arctic to the Antarctic, Biogeosciences, 6, 439-451, 2009, http://www.biogeosciences.net/6/439/2009/.

Walker, S. J., Weiss, R. F., and Salameh. P. K.: Reconstructed histories of the annual mean atmospheric mole fractions for the halocarbons CFC-11, CFC-12, CFC-113 and carbon tetrachloride, J. Geophys. Res., 105, 14285-14296, 2000.

Wallace, D. W. R.: Storage and Transport of Excess $\mathrm{CO}_{2}$ in the Oceans: The JGOFS/WOCE Global $\mathrm{CO}_{2}$ Survey. In: Ocean Circulation and Climate, International Geophysics Series, vol. 77, edited by: Siedler, G., Church, J., and Gould, J., Academic Press, 489-520, 2001.
Wanninkhof, R. Peng, T.-H., Sabine, C. L., and Lee, K.: Comparison of Inorganic Carbon System Parameters Measured in the Atlantic Ocean from 1990 to 1998 and Recommended Adjustments ORNL/CDIAC-140, Carbon Dioxide Information Analysis Center, Oak Ridge National Laboratory, US Department of Energy, Oak Ridge, TN, USA, 43 pp., 2003.

Wanninkhof, R., Doney, S. C., Peng, T. H., Bullister, J. L., Lee, K., and Feely, R. A.: Comparison of methods to determine the anthropogenic $\mathrm{CO}_{2}$ invasion into the Atlantic Ocean, Tellus, 51B, 511-530, 1999.

Warner, M. and Weiss, R.: Solubilities of chorofluorocarbons 11 and 12 in water and seawater, Deep Sea Res., 32, 1485-1497, 1985.

Waugh, D. W., Haine, T. W. N. and Hall, T. M.: Transport times and anthropogenic carbon in the subpolar North Atlantic Ocean, Deep-Sea Res. I, 51, 1475-1491, 2004.

Waugh, D. W., Hall, T. M., McNeil, B. I., Key, R., and Matear, R. J.: Anthropogenic $\mathrm{CO}_{2}$ in the oceans estimated sing transit time distributions, Tellus, 58B, 376-389, 2006.

Weppernig, R., Schlosser, P., Khatiwala, S., and Fairbanks, R. G.: Isotope data from Ice Station Weddell: Implications for deep water formation in the Weddell Sea, J. Geophys. Res., 101, 25723 25739, 1996.

Wetzel P. A., Winguth, A., and Maier-Reimer, E.: Sea-to-air $\mathrm{CO}_{2}$ flux from 1948 to 2003: A model study, Global Biogeochem. Cy., 19, GB2005, doi:10.1029/2004GB002339, 2005.

Yool, A., Martin, A. P., Fernandez, C., and Clark, D. R.: The significance of nitrification for oceanic new production, Nature, 447, 999-1002, doi:10.1038/nature05885, 2007. 